\title{
NEW LOCALITIES OF TARAXACUM SPECIES FROM S POLAND (WITH NINE NEW SPECIES TO POLISH FLORA)
}

\author{
BOHUMIL TRÁVNÍČEK ${ }^{1}$, JOLANTA MARCINIUK ${ }^{2}$, VoJTĚCH ŽÍLA ${ }^{3}$ \\ ${ }^{1}$ Department of Botany, Palacký University, Faculty of Science \\ Svobody 26, 77146 Olomouc, Czech Republic \\ e-mail: travnicek@prfholnt.upol.cz \\ 2 Department of Botany, University of Podlasie \\ Prusa 12, 08-110 Siedlce, Poland \\ e-mail: jolam@ap.siedlce.pl \\ ${ }^{3}$ Mládežnická 1227, CZ-386 01 Strakonice, Czech Republic \\ (Received: April 24, 2006. Accepted: March 22, 2007)
}

\begin{abstract}
A study of the very complex, from the taxonomic point of view, Taraxacum genus was undertaken in the area between the towns of Cieszyn and Bielsko-Biała (S Poland). Taraxacum species belonging to three sections: sect. Hamata H. Øllg. (three species), sect. Palustria (H. Lindb.) Dahlst. (one unidentified taxon), and sect. Ruderalia Kirschner, H. Øllg. et Štěpánek (61 species) were recorded. Nine species new to Poland were found: T. acutifrons Markl., T. ancistratum H. Øllg., T. bellum H. Øllg., T. chrysophaenum Railons., T. deltoidifrons H. Øllg., T. horridifrons Railons., T. pronilobum H. Øllg., T. rhamphodes Hagl., T. violaceifrons Trávníček. Presence of three other species, whose localities hitherto have not been exactly given, was confirmed: T. aberrans Hagendijk, van Soest et Zevenbergen, $T$. fasciatum Dahlst. and T. gibberum Markl. (all they belong to the section Ruderalia). For most species, the details of their occurrence in Poland were also reported. The species new in Poland are briefly described and illustrated with photographs of herbarium specimens.
\end{abstract}

KEY WORDS: Taraxacum, Asteraceae, distribution, S Poland.

\section{INTRODUCTION}

Modern taxonomic studies of the genus Taraxacum in Poland, based on the concept of apomictic microspecies (agamospecies), resulted in a synthetic monograph in Flora of Poland (Tacik 1980). However, this work included mainly the material collected near Cracow, while distribution of most species (found in Poland) outside this region remained unknown. Commencing in the late 1990s, the studies of Polish dandelions have been carried out by a group of taraxacologists directed by professor Z. Głowacki, in cooperation with an expert in taraxacology, H. Øllgaard (Viborg, Denmark). The results of taraxacological studies done in various regions of Poland have been periodically published (see Głowacki et al. 1998; Białasz and Głowacki 1999; Głowacki and Øllgaard 1999; Głowacki and Czarna 2003; Øllgaard et al. 2000, 2002a-c; Głowacki et al. 2004; Grużewska 2004; Głowacki et al. 2005). In these publications, the sites of dandelion occurrence are usually indicated with the information on their situation in the ATPOL grid square system (Zając 1978). The collected data concerning the presence of dandelions in Poland are, in case of most species, incomplete, and insufficient for construction of distribution maps. Nevertheless, the level of the taraxacological knowledge in Poland is improving step by step. These studies also result in successive publication of species new in the Polish flora.

In spring 2005 we carried out a field study, the aim of which was evaluation of species diversity of Taraxacum in the region between the towns of Cieszyn and Bielsko-Biała, in Southern Poland. According to B. Trávníček, co-author of the present study, species diversity of Taraxacum in the adjacent region of the Czech Republic, particularly of section Ruderalia, is very high. Thus, we assumed that a similarly high diversity may occur in the adjacent area of Poland, where taraxacological studies were never performed, and where species new for Polish dandelion flora might be found. The results of our study confirmed this assumption. Doing the three-day survey at eight localities we found 64 identified species of dandelions, including nine species quite new to Poland: T. acutifrons, T. ancistratum, $T$. bellum, $T$. chrysophaenum, $T$. deltoidifrons, $T$. horridifrons, $T$. pronilobum, $T$. rhamphodes, $T$. violaceifrons. In the case of other three species (T. aberrans, $T$. fasciatum, T. gibberum), known from very brief reports (see Tacik 1980; Mirek et al. 2002), and doubtful localities, we gave 
their brief description, and first positive and precise indication of their location in Poland.

\section{MATERIAL AND METHODS}

On May 6-8, 2005 we chosed eight localities in the region between the towns of Cieszyn and Bielsko-Biała. The localities showed studied biotopes appropriate for dandelions: mesophilous and moderately humid hay meadows, and urban lawns. In each of these localities we recorded all the dandelion species we were able to determine - usually we identified the species (or tentative) name for about 70 $-80 \%$ of the plants discovered. However, we limited the herbarium documentation to the most significant objects, such as the species new to Poland, and species having only tentative names (about 15 species), that could not be classified as any of the known taxa. These "work-named" species are known from numerous localities located not only in our study area but also in various regions of the Czech Republic. Further studies are necessary for their taxonomical classification and description, probably as new species. Besides the above mentioned plants, we also collected numerous unidentified specimens belonging to species we had not detected before. These specimens will be used for further comparative taxonomic studies. The voucher herbarium specimens were deposited in herbarium of the Department of Botany, Palacký University Olomouc, Faculty of Science (OL), in herbarium of the Department of Botany, University of Podlasie in Siedlce (WSRP), and in the private herbary owned by V. Žíla (herb. Žíla).

The study localities were numbered, and the situation of each locality was indicated in the map of ATPOL grid square system, with accuracy of square of $1 \times 1 \mathrm{~km}$ (Fig. 1), and their geographic coordinates were directly determined in the field using GPS. The observed species were classified to sections, and within the section listed in alphabetic order. The name of each species is accompanied by numbers and names of localities in which it was found, along with a note concerning herbarium documentation. For each

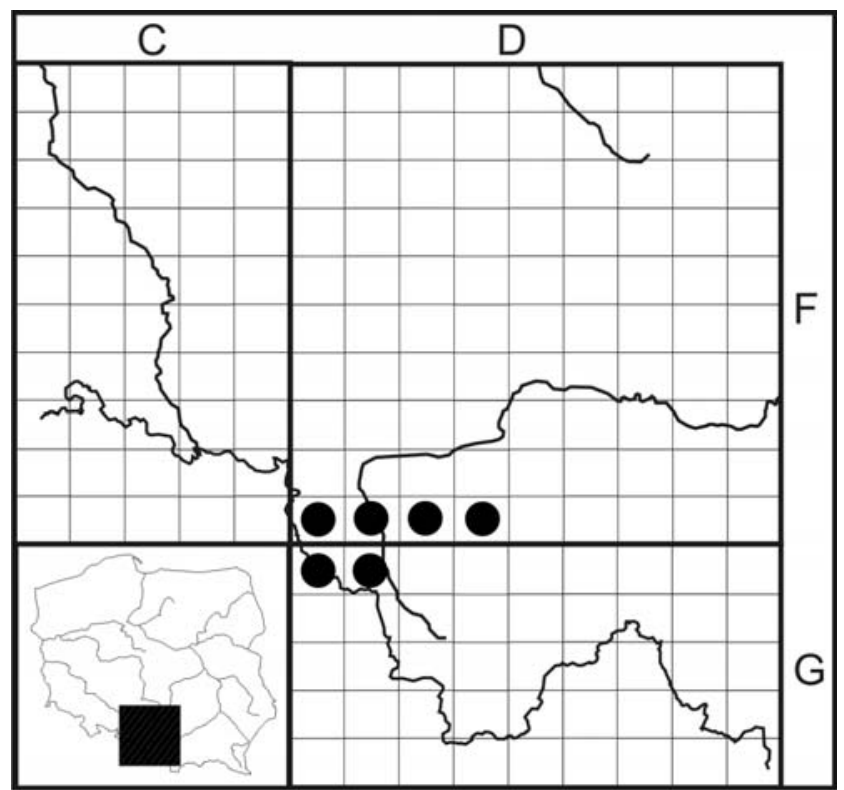

Fig. 1. Location of investigated localities in the area studied in relation to the ATPOL grid square system. species, earlier literature data on its occurrence in Poland are also shown, including indication of ATPOL squares, in which the species was previously determined. For the most significant findings, short comments are also included. Geographic names used in some of these comments are presented in accordance with Kondracki 2002.

\section{INVESTIGATED LOCALITIES}

1 Cieszyn town, lawns and street roadsides $1.1 \mathrm{~km} \mathrm{~S}$ (-SSW) of the main railway station, ca $320 \mathrm{~m}$ a.s.1., $49^{\circ} 44^{\prime} 27^{\prime \prime} \mathrm{N}$, 18³8'04”E, ATPOL: DG0 023, 6. V. 2005.

2 Dzięgielów village near Cieszyn town, small meadow between brook and the road towards Puńców village, in W part of the village, ca $310 \mathrm{~m}$ a.s.1., $49^{\circ} 43^{\prime} 15^{\prime \prime} \mathrm{N}$, 1841'32”E, ATPOL: DG0047, 7. V. 2005.

3. Lipowiec village near Ustroń town, small meadows at the road towards Brenna village, near E margin of the village, ca $400 \mathrm{~m}$ a.s.1., 49 44'58'N, 18 50'03'E, ATPOL: DG0118, 7. V. 2005.

4 Grodziec village near Skoczów town, meadow at the brook $\mathrm{N}$ of the main road on the $\mathrm{S}$ margin of the village, ca 325 m a.s.1., 49 48'00”N, 1851'51'E, ATPOL: DF9250, 7. V. 2005.

5 Bystra village near Bielsko-Biała town, meadow at brook between the village and Mikuszowice Śląskie village, ca $440 \mathrm{~m}$ a.s.1., $49^{\circ} 46^{\prime} 47^{\prime} \mathrm{N}, 1^{\circ} 01^{\prime} 32^{\prime} \mathrm{E}$, ATPOL: DF9371, 7. V. 2005.

6. Międzyrzecze Górne village near Bielsko-Biała town, meadow in brook valley at the road, ca $330 \mathrm{~m}$ a.s.1., 4950'12”N, 1856'52”E, ATPOL: DF9216, 7. V. 2005.

7. Hażlach village near Cieszyn town, lawns and roadsides near the road bridge across Piotrówka brook W of the village, ca $265 \mathrm{~m}$ a.s.1., 4948'22”N, 18³9'34”'E, ATPOL: DF9045, 8. V. 2005.

8 Skoczów town, meadow at the main road Cieszyn-Bielsko-Biała $1.1 \mathrm{~km}$ SE of the railway station in the town center, ca $310 \mathrm{~m}$ a.s.1., 49 47'06”N, 18 47'42'E, ATPOL: DF9175, 8. V. 2005.

\section{LIST OF SPECIES}

Taraxacum Hamata H. Ø llgarard

Taraxacum hamatiforme Dahlstedt in Lindman Svensk Fanerogamfl. 568, 583, 1918.

Recorded localities: 3. Lipowiec (OL, leg. Trávníček), 5. Bystra (OL, leg. Trávníček; herb. Žíla, leg. Žíla; WSRP, leg. Marciniuk), 7. Hażlach (WSRP, leg. Marciniuk), 8. Skoczów (OL, leg. Trávníček).

Former records: AB42, AD04, BE13, CA37, CA38, CA39, DE93, DF43, EF80 (Dziekanowice, "verisim."), FD33 Tacik 1980, Øllgaard et al. 2000, 2002b. 
Taraxacum hamatum Raunkiaer Dansk Ekskursionsfl., ed. 2, 255, 1906.

Recorded locality: 5. Bystra (OL, leg. Trávníček, rev. H. Øllgaard).

Former records: AB42, CA37, CA38, CA39, DA51, EF62 (Błoto) - Tacik 1980; Øllgaard et al. 2000, 2002b.

So far this species has been known from a few localities in NW Poland (South Baltic coast), and from one locality situated east from Cracow. In the neighbouring countries, $T$. hamatum has rarely been found in the Czech Republic (Kirschner and Štěpánek 1995), including the region adjacent to our study area (Trávníček unpubl.), and in E Germany (Uhlemann 2003).

Taraxacum lamprophyllum M. P. Christiansen Dansk Bot. Arkiv 9 (2): 12, 1936.

Recorded localities: 5. Bystra (herb. Žíla, leg. Žíla; WSRP, leg. Marciniuk), 7. Hażlach (OL, leg. Trávníček).

Former records: DE93, EF70 (Cracow-Prokocim, "verisim.”), FC13 - Tacik 1980; Øllgaard et al. 2002a, b.

This species has been found only at three localities in Poland, one of which was reported as uncertain (Cracow-Prokocim). Another locality is situated in NE Poland (the valley of lower Narew River), and the third - NW of Cracow (region Garb Herbski). The occurrence of this species in our study area continues to its distribution in the adjacent region of the Czech Republic (Trávníček unpubl.). The species was found also in E Germany (Uhlemann 2003).

Taraxacum $\$$ p.

Recorded locality: 1. Cieszyn (OL, leg. Trávníček).
Taraxacum Palustria (H. Lindberg) Dahlstedt

Taraxacum $\$$.

Recorded locality: 4. Grodziec (OL, leg. Trávníček).

In our study area, only several specimens of one unknown species belonging to the section Palustria were found in only one locality.

\section{Taraxacum Ruderalia Kirschner H. Ø Ilgaard et Štìpánek}

Taraxacum aberrans Hagendijk, van Soest et Zevenbergen Acta Bot. Neerl. 23: 439, 1974 (Fig. 2)

Main diagnostic features of the species: usually robust plant; leaves almost glabrous, lateral lobes 3-5, regular, most often undivided, patent to slightly recurved; interlobes frequently with plicate margin, the uppermost often rather long; terminal lobe usually large, triangular to helmetshaped; petioles narrowly winged below but often broadly winged in their upper part, light pink to almost (outside) whitish green; outer bracts recurved to reflexed, often crowded, with transverse wrinkle (s), paler green and whitish pruinose in upper surface, almost unbordered.

Recorded localities: 1. Cieszyn (OL, leg. Trávníček; WSRP, leg. Marciniuk), 2. Dzięgielów (OL, leg. Trávníček; herb. Žíla, leg. Žíla; WSRP, leg. Marciniuk), 3. Lipowiec (OL, leg. Trávníček; WSRP, leg. Marciniuk), 4. Grodziec, 5. Bystra (OL, leg. Trávníček), 6. Międzyrzecze Górne (herb. Žíla, leg. Žíla; WSRP, leg. Marciniuk), 7. Hażlach, 8. Skoczów.

Taraxacum aberrans was present at all the localities, and is abundant in the area under study. It is also abundant in the adjacent area of the Czech Republic (Trávníček unpubl.). Our finding confirms the presence of this species in Poland. In this country, the species has been found near Żywiec (unpublished locality, det. Øllgaard; see footnotes in

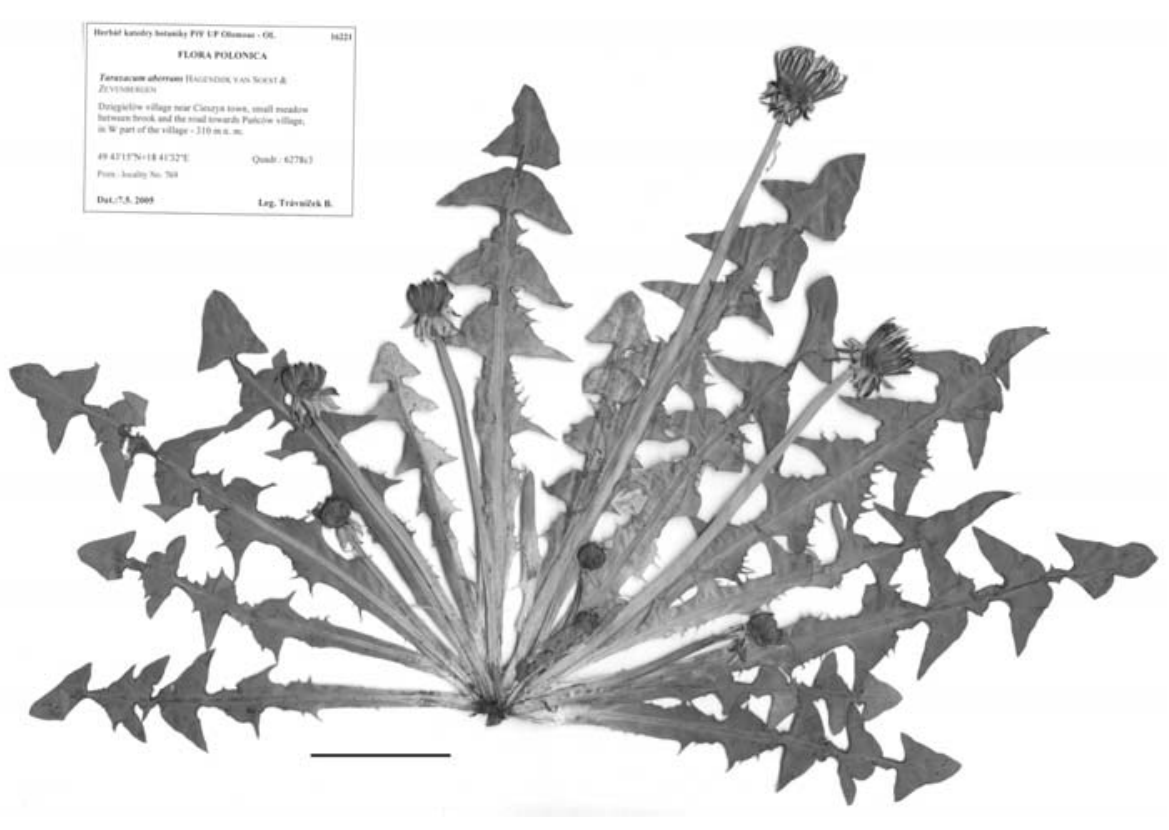

Fig. 2. Taraxacum aberrans, habitus, herbarium specimen, deposited in herbarium OL (locality no. 2); scale bar $=5 \mathrm{~cm}$. 
Mirek et al. 2002). Tacik (1980) reported its "probable" presence in Cracow: "specimens very similar (and maybe belonging?) to T. aberrans were collected in Cracow; however, their taxonomic identity is not quite sure". This species was also found in E Germany (Uhlemann 2003).

Taraxacum acervatulum Railonsala Ann. Bot. Fenn. 1: $125,1964$.

Recorded localities: 1. Cieszyn, 2. Dzięgielów, 7. Hażlach, 8. Skoczów.

Former records: BB04, CD40, DF31, DF54, ED26, EE76, EF25, FB86, FD25, GD00 - Głowacki and Øllgaard 1999; Øllgaard et al. 2000, 2002a, b; Głowacki et al. 2004, 2005.

Taraxacum acroglossum Dahlstedt Arkiv Bot., Stockholm, 9 (10): 31, 1910.

Recorded localities: 1. Cieszyn, 2. Dzięgielów, 4. Grodziec, 5. Bystra, 6. Międzyrzecze Górne, 7. Hażlach.

Former record: BB04 - Øllgaard et al. 2000.

This species has been reported only at one locality in NW Poland (Koszalin Coast). In our study area, it was frequent, similarly as in the adjacent region of the Czech Republic (Trávníček unpubl.). It was found also in Slovakia (Kirschner and Štěpánek 1998) and E Germany (Uhlemann 2003).

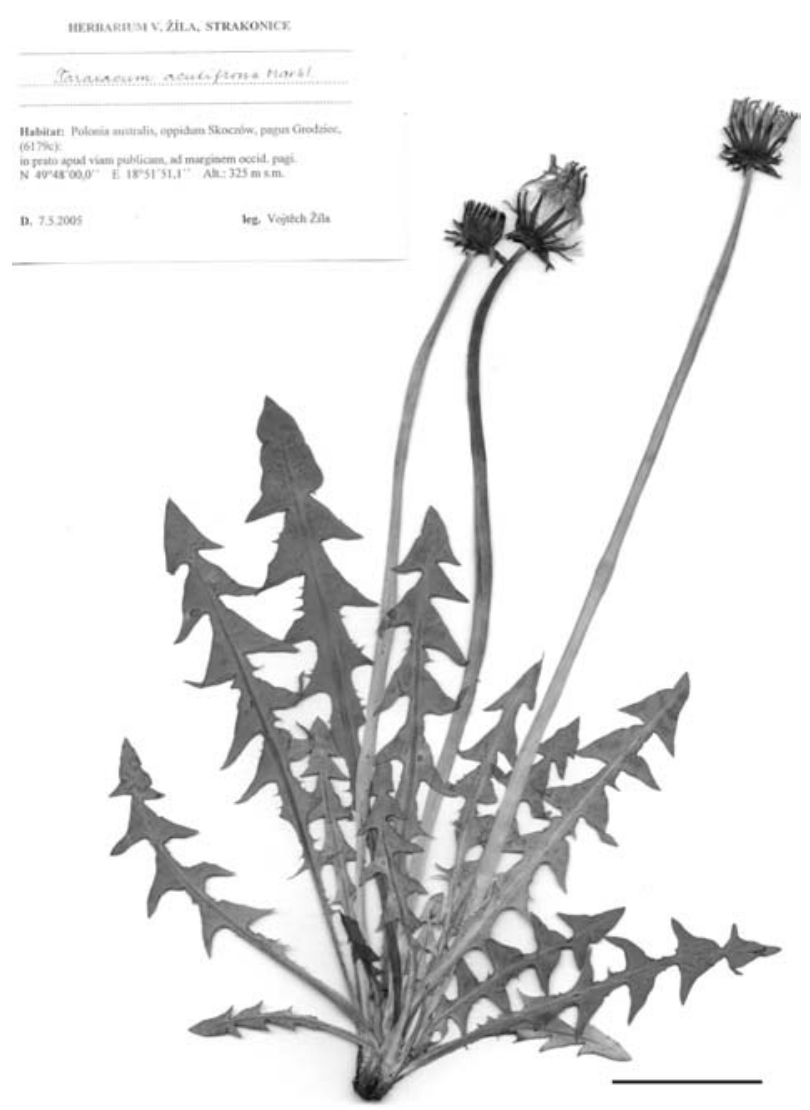

Fig. 3. Taraxacum acutifrons, habitus, herbarium specimen, deposited in herbarium Žíla (locality no. 4); scale bar $=5 \mathrm{~cm}$.
Taraxacum acutifrons Marklund Acta Bot. Fenn. 26: 135, 1940 (Fig. 3)

Main diagnostic features of the species: leaves rather firm, light green, midrib green to slightly coloured; lateral lobes 4-6, regular, upwards gradually verged into interlobes; terminal lobe \pm narrowly triangular to almost hastate, acute at apex, in inner leaves often large; interlobes with slightly undulate margin; petioles narrowly winged, whitish green to faintly pink; scapes usually markedly purple coloured in upper part; outer bracts \pm horizontally spreading, deep purple violet on upper surface, bordered; pollen always present ( $T$. acutifrons somewhat resembles $T$. exsertiforme but $T$. exsertiforme is an apolline species).

Recorded localities: 3. Lipowiec (OL, leg. Trávníček), 4. Grodziec (OL, leg. Trávníček; herb. Žíla, leg. Žíla; WSRP, leg. Marciniuk).

T. acutifrons is a new species for Poland. In our study area only a few specimens were found, at two localities. Distribution in Poland continues to occurence of T. acutifrons in the adjacent region of the Czech Republic where it is dispersed (Trávníček unpubl.). It was found also in E Germany (Uhlemann 2003).

Taraxacum aequilobum Dahlstedt Arkiv Bot., Stockholm, 9 (10): 42, 1910, slt.

Recorded locality: 2. Dzięgielów.

Former records (T. aequilobum): BE25, DF68 (CracowBielany), EG33 (Stolarzówka), FC13 (Łomża, near School No 9), GD00 - Tacik 1980; Głowacki and Øllgaard 1999, Øllgaard et al. 2002b, Grużewska 2004.

This species was found at one locality only, and it was very similar to the typical $T$. aequilobum, but also shows some small differences. This type is probably identical with the taxon recorded (and illustrated) in E Germany (Uhlemann 2003: 57, "Type A"). It is also known from the Czech Republic (Trávníček et al. 2007). Its relation with T. aequilobum s. str. requires further taxonomic studies.

Taraxacum a latum H. Lindberg Acta Soc. Fauna Fl. Fenn. 29 (9): 9, 20, 1908.

Recorded localities: 1. Cieszyn, 2. Dzięgielów (WSRP, leg. Marciniuk), 3. Lipowiec, 4. Grodziec, 5. Bystra (WSRP, leg. Marciniuk), 6. Międzyrzecze Górne (WSRP, leg. Marciniuk), 7. Hażlach, 8. Skoczów.

Former records: AB42, BB04, BD37, BE13, CA39, CD52, DF69 (Cracow), ED11, ED26, EG11 (Gródek), EG20 (Lasek), FB86, FC13 (Łomża), FC14 (Niewodowo), FC49, FC81, FD07, FD16, FD20, FD25, FD33, FD35, FD54, GD41 - Tacik 1980; Głowacki and Øllgaard 1999; Øllgaard et al. 2000, 2002a, b; Grużewska 2004; Głowacki et al. 2005.

Taraxacum altissimm H. Lindberg Acta Soc. Fauna Fl. Fenn. 29 (9): 9, 20, 1908. 
Recorded localities: 2. Dzięgielów (WSRP, leg. Marciniuk), 5. Bystra (herb. Žíla, leg. Žíla).

Former records: DF57 (Krzeszowice), EG33 (Stolarzówka, Gródek), FC81, FD25, FD33 - Tacik 1980; Głowacki and Øllgaard 1999; Øllgaard et al. 2000.

In Poland, T. altissimum has been known from NE part of the country (South Podlasie and Central Mazovia Lowlands), and from Cracow area in S Poland. It was also found in the Czech Republic (Kirschner and Štěpánek 1995), Slovakia (Kirschner and Štěpánek 1998), and in E Germany (Uhlemann 2003).

Taraxacum amplum Marklund Acta Bot. Fenn. 26: 138, 1940.

Recorded localities: 3. Lipowiec, 4. Grodziec, 5. Bystra (WSRP, leg. Marciniuk), 7. Hażlach (WSRP, leg. Marciniuk).

Former records: BB04, BE13 ("verissime"), BE26, CA38, CA39, CD40, CD41, DA51, DD33, DF56 (Dulowa), DF79 (Cracow-Łagiewniki), EC95, EC96, ED14, ED21, ED26, ED29, EE83, EF13, EF72, FB76, FB86, FC13 (the Narew River valley: Łomża, Kalinowo), FC14 (the Narew River valley: Drozdowo), FC64, FD04, FD09, FD16, FD24, FD25, FD26, FD27, FD33, FD35, FE00, GD00, GD23, GE01 (Lejno), GE01 (Lipniak), GE53 - Tacik 1980; Białasz and Głowacki 1999; Głowacki and Øllgaard 1999; Øllgaard et al. 2000, 2002a, b; Głowacki and Czarna 2003; Grużewska 2004; Głowacki et al. 2005.

Taraxacum ancistratum H. Øllgaard Preslia 75: 140, 2003 (Fig. 4)

The species considerably resembles $T$. ancistrolobum, which has the same hamate leaf lobes, pale green petioles and similar outer bracts. From this latter species it differs by its fresh green leaves (not dark, greyish green as in $T$. ancistrolobum), endlobes of inner leaves with more incu- rved side lobule apices, interlobes often with more remarkable teeth, more espressivo bordered outer bracts and by yellowish stigmas (not discoloured as in T. ancistrolobum).

Recorded localities: 1. Cieszyn (OL, leg. Trávníček), 3. Lipowiec (OL, leg. Trávníček), 5. Bystra (OL, leg. Trávníček; herb. Žíla, leg. Žíla), 7. Hażlach (OL, leg. Trávníček).

The recently described species $T$. ancistratum is quite new for Polish flora, and up till now it has been found only in Denmark and the Czech Republic, as probably introduced plant it is recorded from USA (Washington), see Øllgaard (2003). In the Czech Republic, this species occurs only in region adjacent to our study area.

Taraxacum ancistrolobum Dahlstedt Bergens Mus. Aarbok 1923-1924 (6): 27, 1925.

Recorded localities: 1. Cieszyn, 2. Dzięgielów (herb. Žíla, leg. Žíla), 3. Lipowiec, 4. Grodziec, 5. Bystra, 6. Międzyrzecze Górne (WSRP, leg. Marciniuk), 7. Hażlach.

Former records: AB52, BE13, CA37, CA39, DF69 (Cracow), FC13 (Narew River valley: Kalinowo - two localities), FC56, FC64, FC74, FC99, FD07, FD25, FD27 - Tacik 1980; Głowacki and Øllgaard 1999; Øllgaard et al. 2000, 2002b; Grużewska 2004.

Taraxacum atrox Kirschner et Štěpánek Preslia 69: 55, 1997.

Recorded localities: 2. Dzięgielów, 6. Międzyrzecze Górne, 7. Hażlach, 8. Skoczów.

Former record: EF20 - Øllgaard et al. 2002c.

In Poland, T. atrox has been known from a single locality in the SE part of the country (Miechów Upland). The new localities continue to scattered distribution of this species in the adjacent region of the Czech Republic (Trávníček

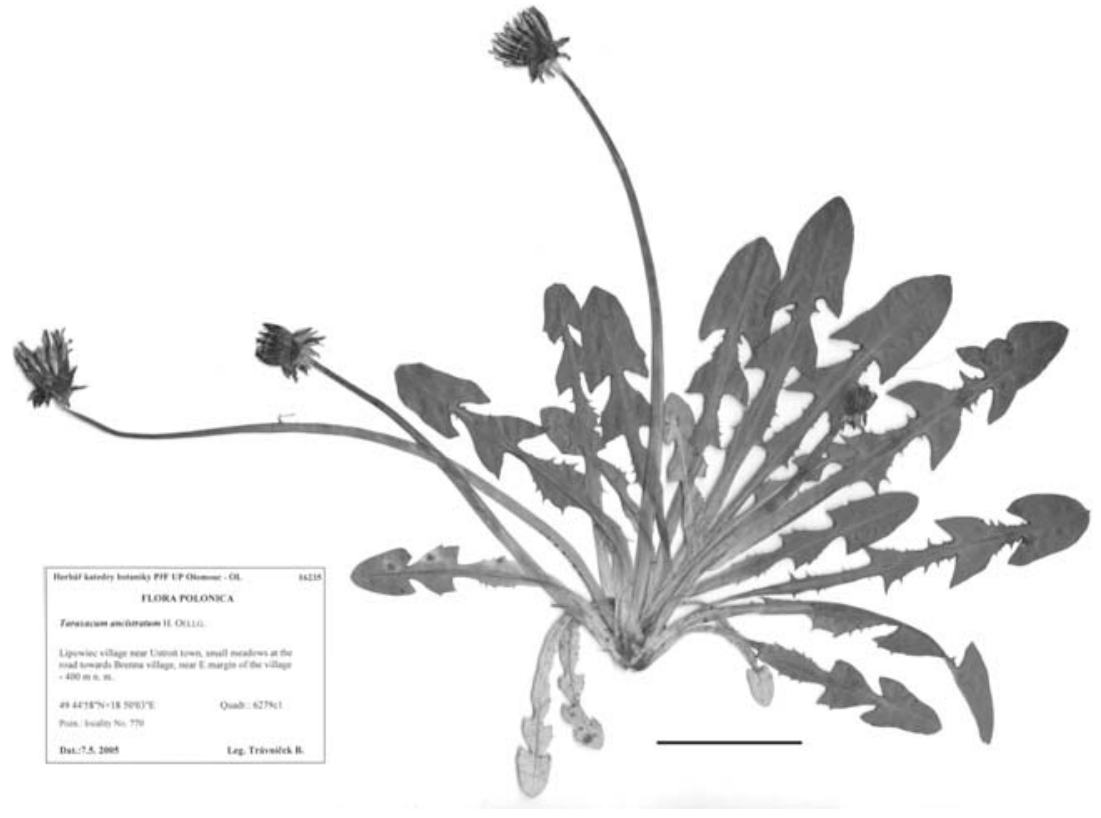

Fig. 4. Taraxacum ancistratum, habitus, herbarium specimen, deposited in herbarium OL (locality no. 3 ); scale bar $=5 \mathrm{~cm}$. 
unpubl.). T. atrox was found also in E Germany (Uhlemann 2003).

Taraxacum aurosulum H. Lindberg Meddel. Soc. Fauna Fl. Fenn. 35: 14, 1909.

Recorded localities: 1. Cieszyn (herb. Žíla, leg. Žíla; WSRP, leg. Marciniuk), 2. Dzięgielów (OL, leg. Trávníček; herb. Žíla, leg. Žíla), 3. Lipowiec (OL, leg. Trávníček; herb. Žíla, leg. Žíla; WSRP, leg. Marciniuk), 4. Grodziec (OL, leg. Trávníček; herb. Žíla, leg. Žíla; WSRP, leg. Marciniuk), 6. Międzyrzecze Górne (herb. Žíla, leg. Žíla), 7. Hażlach (herb. Žíla, leg. Žíla).

Former record: EF33 (Cracow-Swoszowice) - Tacik 1980.

In the study area, the species is fairly frequent, similarly as in the adjacent region of the Czech Republic. In this country, however, it is generally a rare species, the most abundantly occurring near town of Český Těšín (Trávníček unpub.). It was found also in E Germany (Uhlemann 2003). In Poland, it has been reported from Cracow area. Presumably, this very distinct taxon rarely overlooked in taraxacological studies belongs to the species the presence of which is in Poland limited to some specific areas.

Taraxacum bellum H. Øllgaard Bot. Notiser 131: 502, 1978 (Fig. 5)

T. bellum belongs to species group of sect. Ruderalia with remarkable dissected leaves with narrow lobes and many teeth and narrowly winged pink-violet petioles. By Øllgaard (1978), T. bellum resembles T. altissimum, but has light-coloured leaves, the lateral lobes of which are often club-shaped and more obtuse than those of T. altissimum and with more and longer teeth on the lower margins of the lobes. The outer bracts of $T$. bellum have broader margins than those of $T$. altissimum and the ligules are not red-tipped as in the latter species.

Recorded locality: 3. Lipowiec (OL, leg. Trávníček, rev. H. Øllgaard; herb. Žíla, leg. Žíla).

T. bellum is a new species for Polish flora, several specimens were found at a single locality only. In adjacent countries, the species was found in the Czech Republic (see Kirschner and Štěpánek 1995), where its occurence is scattered (also in region adjacent to our study area) and in Germany (Sackwitz et al. 1998).

Taraxacum brachylepis Marklund ex Puolanne Mem. Soc. Fauna Fl. Fenn. 8: 145, 1933.

Recorded locality: 5. Bystra (OL, leg. Trávníček; herb. Žíla, leg. Žíla).

Former record: DF69 (Cracow-Bonarka) - Tacik 1980.

In Poland, T. brachylepis has been found at a single locality near Cracow. This, quite distinct, taxon is probably present only in some areas in Poland. In neighbouring countries, this species was found in the Czech Republic (Trávníček et al. 2000).

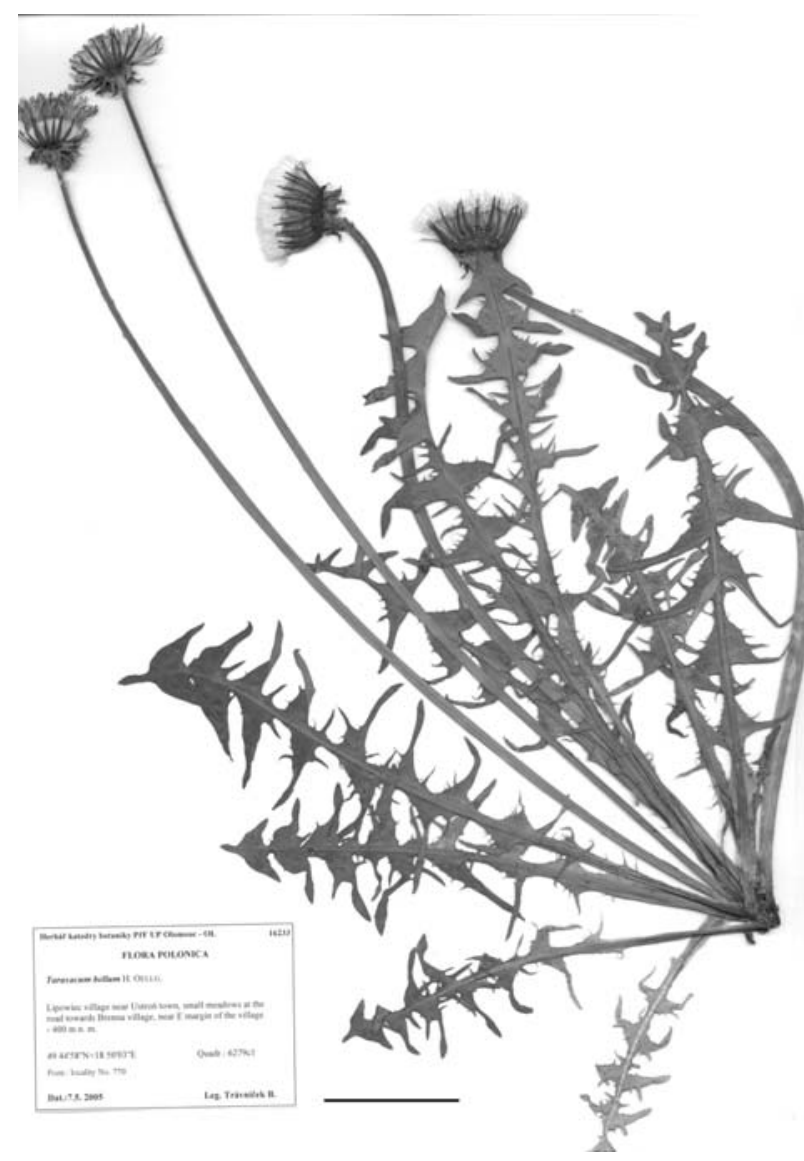

Fig. 5. Taraxacum bellum, habitus, herbarium specimen, deposited in herbarium OL (locality no. 3 ); scale bar $=5 \mathrm{~cm}$.

Taraxacum chrysophaenum Railonsala Archiv. Soc. Vanamo 11: 151, 1957 (Fig. 6)

The species belongs to relatives of $T$. piceatum. Main diagnostic features to its recognition: leaves usually erect, regularly divided, mid-green, not obviously blotched, with green to slightly coloured midrib; lateral lobes 5-8, regular, rather short, patent to slightly recurved, most often with convex distal margin; interlobes short and rather broad; terminal lobe usually not large, triangular to helmet-shaped; petioles more or less winged, whitish green (very rare slightly pink coloured); outer bracts patent to recurved, pale green and \pm pruinous on upper surface, later often slightly purple coloured, almost unbordered.

Recorded localities: 3. Lipowiec (OL, leg. Trávníček), 5. Bystra (OL, leg. Trávníček), 7. Hażlach (WSRP, leg. Marciniuk), 8. Skoczów (OL, leg. Trávníček; herb. Žíla, leg. Žíla; WSRP, leg. Marciniuk).

The species is new for Polish flora. General distribution area of $T$. chrysophaenum is poorly known. In the Czech Republic, known occurence of $T$. chrysophaenum is restricted mainly to the region adjacent to our study area (Trávníček unpubl.). It is also known from Germany (Sackwitz et al. 1998).

Taraxacum copidophyllum Dahlstedt Arkiv Bot., Stockholm, 9 (10): 25, 1910. 


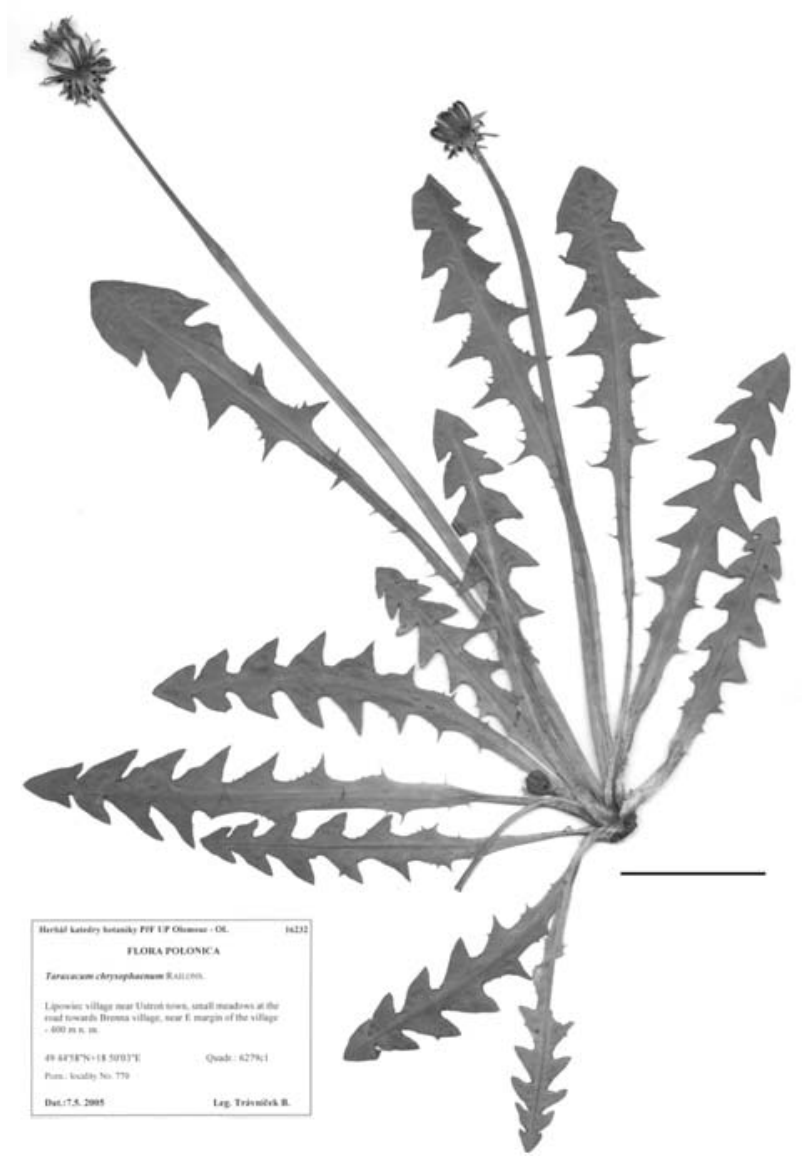

Fig. 6. Taraxacum chrysophaenum, habitus, herbarium specimen, deposited in herbarium OL (locality no. 3); scale bar $=5 \mathrm{~cm}$.

Recorded localities: 5. Bystra (herb. Žíla, leg. Žíla), 7. Hażlach (herb. Žíla, leg. Žíla), 8. Skoczów.

Former records: BD18, BD87 (Bojanowo), CA37, CA39, CD50, DA51, DE93, DF03, DF66, EC94 ("verissime"), ED07, ED11, ED26, ED29, ED95, EF73 (Bochnia), FD16, FD23, FD24, FD25 - Tacik 1980; Głowacki and Øllgaard 1999; Øllgaard et al. 2000, 2002b; Głowacki et al. 2004, 2005.

Taraxacum corynodes Haglund Bot. Notiser 1943: 235, 1943.

Recorded localities: 2. Dzięgielów (herb. Žíla, leg. Žíla), 3. Lipowiec (herb. Žíla, leg. Žíla), 5. Bystra (herb. Žíla, leg. Žíla).

Former records: BE13, DA51, DF78 (Podgórki), DF69 (Bronowice Wielkie), ED14, FC55, FC83 ("verissime"), FC99, GD23 - Tacik 1980; Głowacki and Øllgaard 1999; Øllgaard et al. 2000, 2002b.

Taraxacum crassum H. Øllgaard et Trávníček Preslia 75: $142,2003$.

Recorded localities: 1. Cieszyn, 2. Dzięgielów, 3. Lipowiec (WSRP, leg. Marciniuk), 5. Bystra (WSRP, leg. Marciniuk), 7. Hażlach, 8. Skoczów.

Former records: EF25, FD26 - Øllgaard et al. 2002c.
T. crassum is a recently described species, known in Poland at two localities: in SE Poland (Nida River valley Garb Pińczowski), and in NE Poland (Central Mazovia Lowland - middle Vistula River valley). In neighbouring countries, it was found in the Czech Republic, where it is frequent in almost all the country, in Slovakia, and E Germany (see Øllgaard 2003; Uhlemann 2003). Abundance of this species in our study area is similar to that found in the adjacent region of Silesian part of Moravia (in the Czech Republic).

Taraxacum croceiflorum Dahlstedt Arkiv Bot., Stockholm, 9 (10): 9, 1910.

Recorded localities: 3. Lipowiec (OL, leg. Trávníček; WSRP, leg. Marciniuk), 4. Grodziec (herb. Žíla, leg. Žíla), 5. Bystra (OL, leg. Trávníček; herb. Žíla, leg. Žíla; WSRP, leg. Marciniuk), 6. Międzyrzecze Górne (OL, leg. Trávníček; WSRP, leg. Marciniuk), 8. Skoczów (OL, leg. Trávníček).

Former records: DE93, DF58 (Radwanowice), DF69 (Cracow), FB86, FC13, FC14 (Drozdowo), FC81, FC99, FD07, FD24, FD25 - Tacik 1980; Głowacki and Øllgaard 1999; Øllgaard et al. 2002a, b; Grużewska 2004.

Up till now, this species has been reported from E part of Poland only. Also in the Czech Republic, it has been found only in the NE areas of the country (Trávníček unpubl.). Uhlemann (2003) did not report the presence of this species in E Germany.

Taraxacum deltoidifrons H. Øllgaard Preslia 75: 149, 2003 (Fig. 7)

Main diagnostic features of the species: a medium sized squat plant; leaves spreading, most often greyish green, usually hairy, midrib green to faintly reddish; lateral lobes patent do somewhat declining, \pm undivided, in outer leaves often with a club-shaped outer part, distal margin very often with conspicuous tooth; interlobes \pm flat; terminal lobe usually small, most often triangular; petioles winged, with more or less expressive purplish-red coloration; outer bracts rather narrow and long, usually reflexed, greyish green to dark reddish, unbordered; outer ligules flat, with reddish apical teeth.

Recorded locality: 8. Skoczów (OL, leg. Trávníček).

$T$. deltoidifrons is a recently described species, now found as a new species for Poland. It is known from Denmark, Germany and the Czech Republic (Øllgaard 2003), in the latter its occurence is scattered. Finding more localities in S Poland seems to be very probable.

Taraxacum diastematicum Marklund Acta Bot. Fenn. 26: $141,1940$.

Recorded localities: 5. Bystra (OL, leg. Trávníček; WSRP, leg. Marciniuk), 7. Hażlach (OL, leg. Trávníček).

Former records: BE13, FB76, FC13 (Łomża, Kalinowo), FC14 (Drozdowo), FC40, FC44, FC52, FC74, FC99, FD25 


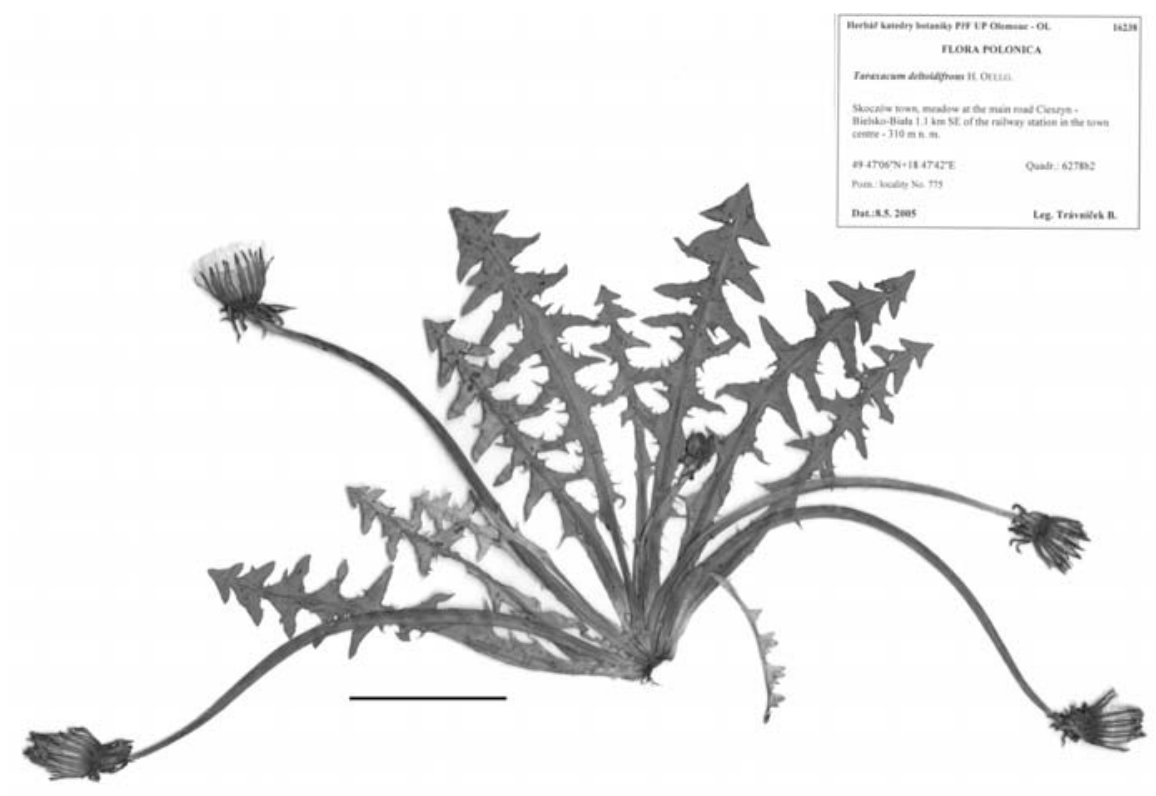

Fig. 7. Taraxacum deltoidifrons, habitus, herbarium specimen, deposited in herbarium OL (locality no. 8); scale bar $=5 \mathrm{~cm}$.

- Głowacki and Øllgaard 1999; Øllgaard et al. 2000, 2002a, b; Grużewska 2004.

Taraxacum ekmanii Dahlstedt Arkiv Bot., Stockholm, 10 (6): 19, 1911.

Recorded localities: 1. Cieszyn, 2. Dzięgielów, 4. Grodziec, 5. Bystra, 6. Międzyrzecze Górne, 7. Hażlach.

Former records: AB25, AB52, AB63, BC99, BD36, BD39, BE13, BE18, BE26, CA37, CA38, CA39, CD40, CD41, CF69, DA51, DC18, DE72, DE93, DF43, DF69 (Cracow), DG07, DG14, EC94, EC95, EC96, ED04, ED05, ED06, ED14, ED26 ("verissime"), ED29, ED39, EE09, EE76, EF13, EF72, EG20 (Lasek), FB76, FB77, FB86, FC13, FC14 (Drozdowo), FC52, FC55, FC64, FC72, FC73, FC74, FC81, FC94, FC95, FC99, FD07, FD09, FD16, FD20, FD23, FD24, FD25, FD27, FD33, FD35, FD45, FE01, GB83, GD00, GD23, GD24, GE01 (Stare Załucze), GE02, GE12 (Sęków) - Tacik 1980; Białasz and Głowacki 1999; Głowacki and Øllgaard 1999; Øllgaard et al. 2000, 2002a, b; Grużewska 2004; Głowacki et al. 2004, 2005.

Taraxacum exsertiforme Hagendijk, van Soest et Zevenbergen Acta Bot. Neerl. 27: 308, 1978.

Recorded localities: 1. Cieszyn (WSRP, leg. Marciniuk), 2. Dzięgielów (WSRP, leg. Marciniuk), 3. Lipowiec (WSRP, leg. Marciniuk), 4. Grodziec, 5. Bystra (WSRP, leg. Marciniuk), 6. Międzyrzecze Górne, 7. Hażlach, 8. Skoczów.

Former record: BB04 - Øllgaard et al. 2000.

In Poland, this species has been recorded at a single locality in NW part of the country (Koszalin Coast). In our study area, it was abundantly present at all localities, similarly as in the adjacent region of the Czech Republic (Trávníček unpubl.). It was also found in E Germany (Uhlemann 2003).
Taraxacum fasciatum Dahlstedt Bot. Stud. Kjellman 172, 1906 (Fig. 8)

Main diagnostic features of the species: leaves mid to dark greyish green, hairy, obviously blotched (tar-coloured) on interlobes; lateral lobes (3-)4-5, regular, patent or recurved, acute at apex; interlobes sometimes with plicate margin;

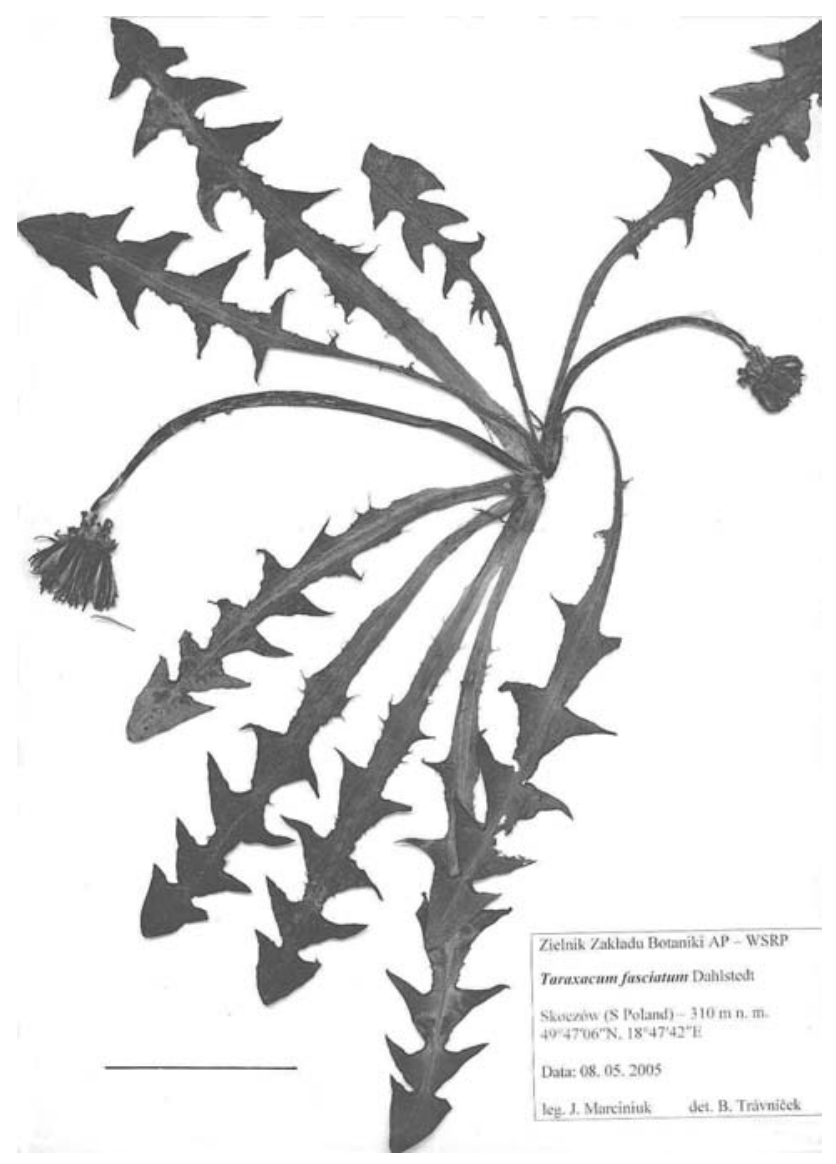

Fig. 8. Taraxacum fasciatum, habitus, herbarium specimen, deposited in herbarium WSRP (locality no. 8 ); scale bar $=5 \mathrm{~cm}$. 
terminal lobe triangular to helmet-shaped; petioles narrowly winged, pale rose to dull reddish; outer bracts most often recurved, pale green, with narrow dark margins on upper surface, later somewhat suffused with light purple.

Recorded localities: 5. Bystra, 8. Skoczów (WSRP, leg. Marciniuk).

In Poland, the species has been found near Żywiec (unpublished locality; see footnotes in Mirek et al. 2002), and at a single uncertain locality in S part of the country - Tacik 1980: ATPOL: EF72 (“Cikowice near Bochnia, leg. Tacik; identification uncertain but very probable"). The rare occurence in Poland is quite surprising since in the Czech Republic this species is common, and was found also in Slovakia (Kirschner and Štěpánek 1998) and in E Germany (Uhlemann 2003).

Taraxacum gibberum Marklund Acta Soc. Fauna Fl. Fenn. 55 (5): 3, 1926 (Fig. 9)

Main diagnostic features of the species: a medium sized, rather slender plant; leaves pale to mid-green, only slightly hairy, with little to markedly divided lobes, sometimes forming acute lobules, midrib often suffused with red; lateral lobes 5-8, rather short, with convex to sigmoid distal margin; interlobes short; terminal lobe sometimes elongated; petioles narrowly winged to almost without wings, whitish green to slightly dull reddish; outer bracts rather narrow, somewhat irregular, mainly patent, unbordered, pale green, later frequently suffused with purple.

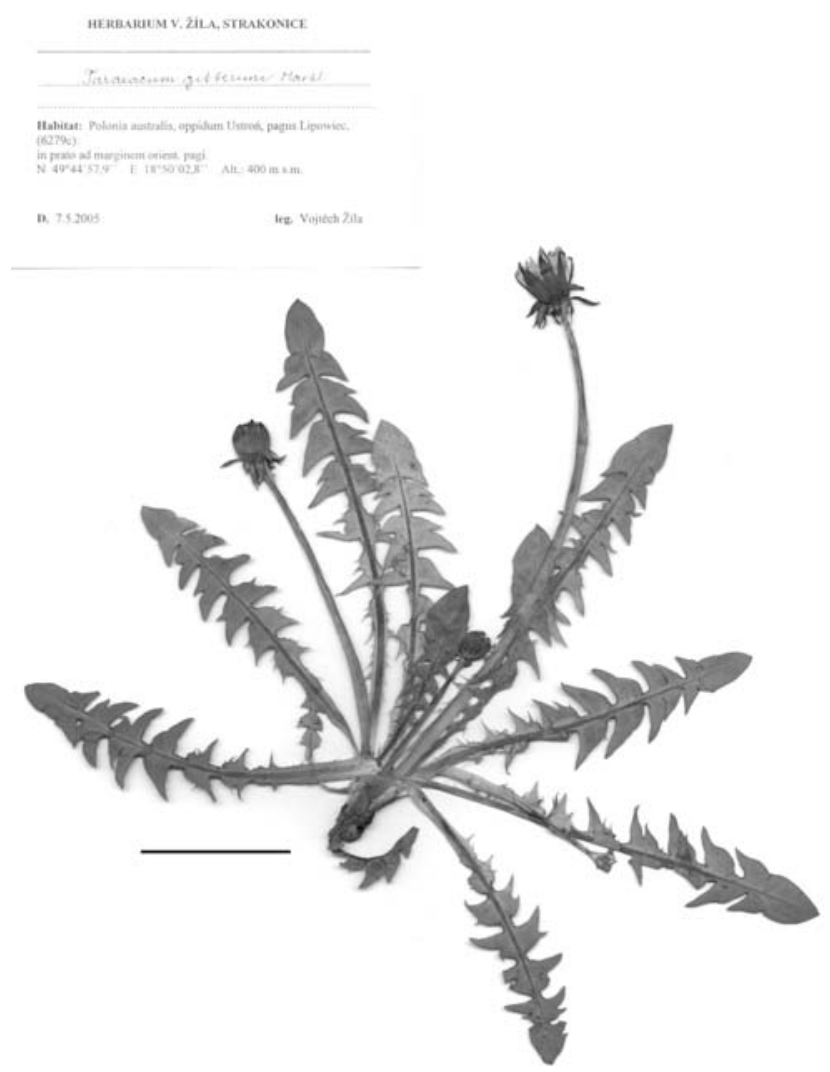

Fig. 9. Taraxacum gibberum, habitus, herbarium specimen, deposited in herbarium Žíla (locality no. 3); scale bar $=5 \mathrm{~cm}$.
Recorded localities: 2. Dzięgielów (OL, leg. Trávníček), 3. Lipowiec (OL, leg. Trávníček; herb. Žíla, leg. Žíla; WSRP, leg. Marciniuk).

T. gibberum is a morphologically distinct species, found rarely, at only two localities. The ascertained distribution in our study area continues to the adjacent area of the Czech Republic (it is limited almost exclusively to this single region in this country - Trávníček unpubl.). In Poland, this species has been found at one (uncertain) locality near Cracow (Tacik 1980: DF69, Cracow-Bronowice, "possible $T$. gibberum"). This species was found also in Germany (Sackwitz et al. 1998), but Uhlemann (2003) did not observe it in the E part of this country.

Taraxacum guttigest ans H. Øllgaard Preslia 64: 26, 1992.

Recorded localities: 1. Cieszyn (WSRP, leg. Marciniuk), 2. Dzięgielów (herb. Žíla, leg. Žíla), 6. Międzyrzecze Górne, 8. Skoczów (WSRP, leg. Marciniuk).

Former records: FC99, FD25, GD00 - Głowacki and Ø11gaard 1999; Øllgaard et al. 2000.

T. guttigestans has been found only in SE part of Poland (South Podlasie Lowland - the Podlasie Bug Gorge, Siedlce Plateau). The new localities reflect distribution of this species in the adjacent region of the Czech Republic (Trávníček unpubl.), it is known also from Slovakia (Kirschner and Štěpánek 1998) and E Germany (Uhlemann 2003).

Taraxacum hemicyclum Haglund in Holmgren Bleking. Fl. 334, 1942.

Recorded localities: 2. Dzięgielów, 4. Grodziec, 6. Międzyrzecze Górne.

Former records: AD05, BC99, BD18, BD37, BE18, CA37, CA38, CA39, CB09, CD32, CD40, DA51, DD33, DF58 (Zabierzów), EC95, EC96, ED04, ED05, ED14, ED15, ED26 ("verissime"), ED29, ED31, ED39, EE09, EE76, EF13, FB76, FB77, FB86, FC13 (Łomża), FC14 (Niewodowo), FC55, FC71, FC74, FC99, FD07, FD09, FD16, FD20, FD23, FD25, FD26, FD27, FD36, FD75, FE00, FG81, GD00, GD31, GD64, GE01 (Stare Załucze, Lipniak, Lejno), GE02 (Wiązowiec) - Tacik 1980; Białasz and Głowacki 1999; Głowacki and Øllgaard 1999; Øllgaard et al. 2000, 2002a, b; Głowacki and Czarna 2003; Grużewska 2004; Głowacki et al. 2005.

Taraxacum hepaticum Railonsala Archiv. Soc. Vanamo 11: $157,1957$.

Recorded localities: 1. Cieszyn, 2. Dzięgielów (WSRP, leg. Marciniuk), 3. Lipowiec (WSRP, leg. Marciniuk), 4. Grodziec, 5. Bystra (WSRP, leg. Marciniuk), 6. Międzyrzecze Górne (WSRP, leg. Marciniuk), 7. Hażlach, 8. Skoczów.

Former records: BB04, BE13, CD40, CF86, DA51, DE93, DG64, ED04, ED11, EE09, FB86, FC13 (Łomża, Marianowo, Kalinowo), FC52, FC55, FC81, FC99, FD09, FD25, FD33, FE01, FE19, GD23 - Głowacki and Øllgaard 1999; 


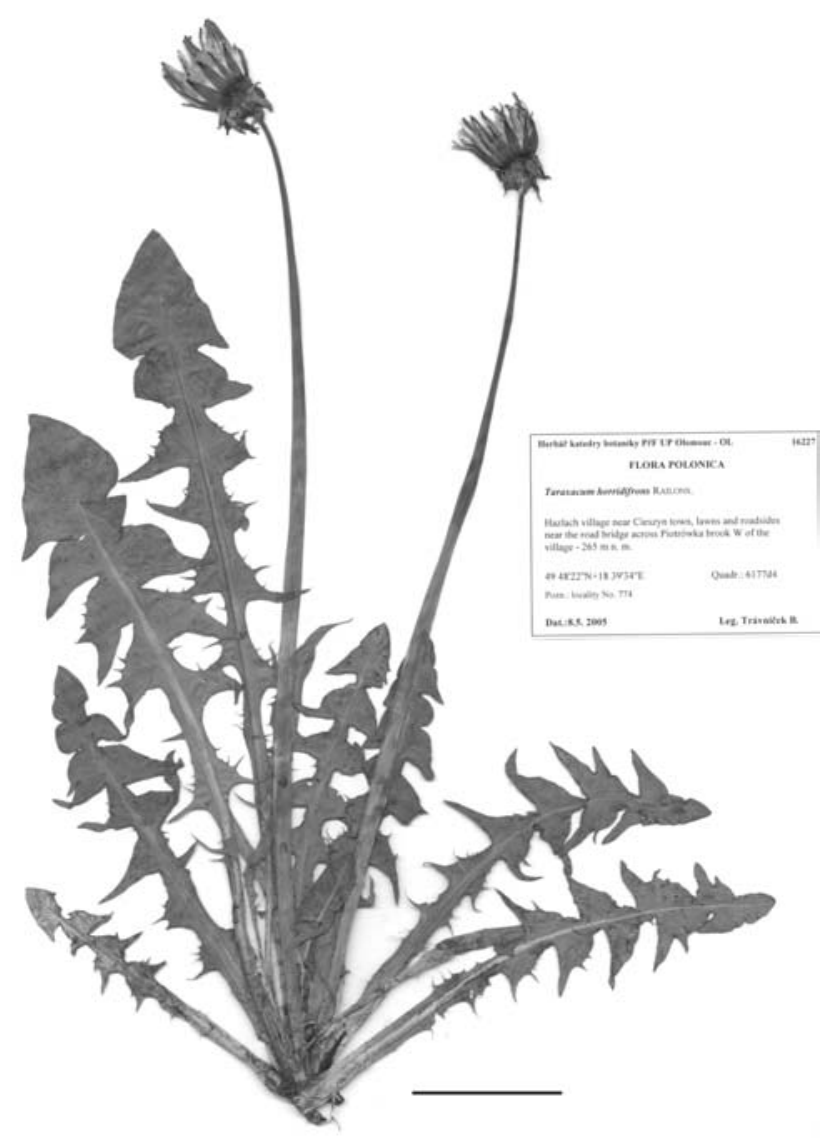

Fig. 10. Taraxacum horridifrons, habitus, herbarium specimen, deposited in herbarium OL (locality no. 7); scale bar $=5 \mathrm{~cm}$.

Øllgaard et al. 2000, 2002a, b; Grużewska 2004; Głowacki et al. 2004, 2005.

Taraxacum horridifrons Railonsala Ann. Bot. Fenn. 4: 106, 1967 (Fig. 10)

Main diagnostic features of the species: rather robust plant; leaves erect, mid to dark greyish green; lateral lobes 4-6, sometimes irregularly divided, usually slightly recurved, with distal margin convex or sigmoid, often with \pm elongated, very acute patent apex; interlobes short; terminal lobe of inner leaves often large; petioles green (very rare inconspicuously light pink coloured), winged; outer bracts recurved to reflexed, grey green and \pm pruinous on upper surface, with vinaceous tip (particularly on a past blossoming capitulum); capitulum relatively light yellow with almost flat outer ligules.

Recorded localities: 3. Lipowiec (OL, leg. Trávníček), 7. Hażlach (OL, leg. Trávníček).

T. horridifrons is a new species for Polish flora. At both mentioned localities it occurs quite rare. This taxon was found also in the Czech Republic (Kirschner and Štěpánek 1995) and E Germany (Uhlemann 2003). Rather abundant occurence of $T$. horridifrons in the Czech Republic suggests a probability of finding another localities in S Poland.

Taraxacum infuscatum H. Øllgaard Preslia 75: 152, 2003.

Recorded locality: 1. Cieszyn (OL, leg. Trávníček; herb. Žíla, leg. Žíla).
Former record: DA51 - Øllgaard et al. 2002c.

$T$. infuscatum is a recently described species, earlier observed at a single locality in NW Poland (Gdańsk and Kaszuby Coast). The locality found in Cieszyn town is therefore very distant from the formerly observed. It is noteworthy that this species has not been observed either in the adjacent (eastern) part of the Czech Republic, or in Slovakia.

Taraxacum ingens Palmgren Acta Soc. Fauna Fl. Fenn. 34: 17, 1910.

Recorded localities: 2. Dzięgielów, 3. Lipowiec, 4. Grodziec (WSRP, leg. Marciniuk), 8. Skoczów.

Former records: BE26, DF69 (Cracow, Wawel, "verisim.”), ED26 - Tacik 1980; Głowacki and Øllgaard 1999; Øllgaard et al. 2002b.

The species has been known in Poland from three localities only, situated in various regions of the country. Besides an uncertain locality in Cracow, it was observed in NE Poland (Central Mazovia Lowland - Warsaw Plain), and in SW part of the country (Rościsławice Plain). In adjacent countries, this species was found in the Czech Republic (Kirschner and Štěpánek 1995), Slovakia (Kirschner and Štěpánek 1998), and E Germany (Uhlemann 2003).

Taraxacum interveniens Haglund Bot. Notiser 1936: 58, 1937.

Recorded localities: 5. Bystra (herb. Žíla, leg. Žíla), 7. Hażlach.

Former records: AB25, BD18, BE26, CA38, DD39, DF25, DF42, DF52, DF69 (Cracow, Lubicz Str.), EC96 ("verissime"), EE74, FB76, FB86, FC13 (Łomża, Marianowo, Kalinowo), FC52, FC55, FC99, FD09, FD20, FD25, FD27, FD33, FE01, GD23 - Tacik 1980; Głowacki and Øllgaard 1999; Øllgaard et al. 2000, 2002a, b; Grużewska 2004; Głowacki et al. 2004, 2005.

Taraxacum jugiferu m H. Øllgaard Preslia 75: 157, 2003.

Recorded localities: 4. Grodziec (OL, leg. Trávníček; WSRP, leg. Marciniuk), 6. Międzyrzecze Górne (OL, leg. Trávníček).

Former record: EF13 - Øllgaard et al. 2002c.

T. jugiferum is a recently described species, in Poland formerly found at a single locality, in SE part of the country (Nida Basin - the Nida River Valley). The species was also observed in Denmark, Germany, Austria and the Czech Republic (Øllgaard 2003), in the latter it has scattered occurence.

Taraxacum lacerifolium Haglund Bot. Notiser 946: 350, 1946.

Recorded localities: 3. Lipowiec (herb. Žíla, leg. Žíla; WSRP, leg. Marciniuk), 7. Hażlach (herb. Žíla, leg. Žíla), 8. Skoczów (herb. Žíla, leg. Žíla). 
Former records: BC99, DE93, DF68 (Zabierzów) - Tacik 1980; Øllgaard et al. 2002b, Głowacki et al. 2005.

In Poland, the species has been reported from three localities only: one locality is situated in W part of country, but two localities in central part of S Poland, i.e. the regions situated near our study area. T. lacerifolium is a very distinct species, overlooking of which is little probable. Thus, this it is supposed that its occurence in Poland is limited to some specific regions only. The three ascertained localities in our study area continue to rather abundant occurence in the adjacent region of the Czech Republic (Trávníček unpubl.) - it is noteworthy that $T$. lacerifolium is the most numerous mainly in this part of the Czech Republic. It was observed also in E Germany (Uhlemann 2003).

Taraxacum laticordatum Marklund Acta Bot. Fenn. 23: $101,1938$.

Recorded localities: 1. Cieszyn (WSRP, leg. Marciniuk), 2. Dzięgielów (OL, leg. Trávníček), 3. Lipowiec (WSRP, leg. Marciniuk), 5. Bystra (WSRP, leg. Marciniuk), 6. Międzyrzecze Górne, 7. Hażlach, 8. Skoczów.

Former records: AB25, BB04, BE18, BE27, EC94, ED29, ED26 ("verissime"), ED33, EG31 (Dębno, "probable" $T$. laticordatum), FB77, FC13 (Łomża, Kalinowo), FC99, FD07, FD25, GD23 - Tacik 1980; Głowacki and Øllgaard 1999; Øllgaard et al. 2000, 2002a, b; Grużewska 2004.

Taraxacum lingulatum Marklund Acta Soc. Fauna Fl. Fenn. 55: 20, 1926.

Recorded localities: 7. Hażlach, 8. Skoczów.

Former records: BB04, CA38, EC59, ED11, ED49, EG20 (Lasek), FB86, FC99, FD24, FD25, FD43, GD00, GD23 Tacik 1980; Głowacki and Øllgaard 1999; Øllgaard et al. 2000, 2002a, b.

Taraxacum lucidum Dahlstedt Arkiv Bot., Stockholm, 9 (10): 27, 1910.

Recorded localities: 2. Dzięgielów (herb. Žíla, leg. Žíla), 4. Grodziec, 6. Międzyrzecze Górne, 7. Hażlach, 8. Skoczów.

Former records: DF69 (Cracow-Bronowice Wielkie, "probably" T. lucidum), FB86, FC74, FC81, FC99, FD07, FD24, FD25 - Tacik 1980; Głowacki and Øllgaard 1999; Øllgaard et al. 2000, 2002a.

In Poland, the species has been found in a few localities in E part of the country. In adjacent countries, it was observed also in the Czech Republic (Kirschner and Štěpánek 1995), Slovakia (Kirschner and Štěpánek 1998) and E Germany (Uhlemann 2003).

Taraxacum macranthoides Haglund Bot. Notiser 1943: 239, 1943.

Recorded localities: 1. Cieszyn, 2. Dzięgielów, 5. Bystra (WSRP, leg. Marciniuk), 6. Międzyrzecze Górne, 8. Skoczów.
Former records: BB04, DF57 (Krzeszowice, "probable" $T$. macranthoides) - Tacik 1980; Øllgaard et al. 2000.

T. macranthoides has been known from two localities in Poland only: near Cracow (uncertain locality), and Koszalin Coast region in NW part of the country. Fairly high frequency of this species in our study area reflects similar abundance in the Czech Republic (see Kirschner and Štěpánek 1995). It was observed also in E Germany (Uhlemann 2003).

Taraxacum macul atum Jordan Pugill. Pl. Nov. 117, 1852.

Recorded localities: 4. Grodziec (WSRP, leg. Marciniuk), 6. Międzyrzecze Górne.

Former records: DF45, DF69 (Wola Justowska, Błonia), DG14, FC99 - Tacik 1980; Øllgaard et al. 2000; Głowacki et al. 2004.

In Poland, the species has been observed in two regions: southern (Cracow Gate, Jaworznickie Hills, Żywiec Basin) and north-eastern (South Podlasie Lowland - Podlasie Bug River Gorge) parts of the country. This species was found also in the Czech Republic (Kirschner and Štěpánek 1995), Slovakia (Kirschner and Štěpánek 1998), and E Germany (Uhlemann 2003).

Taraxacum oblongatum Dahlstedt in Druce Rep. Bot. Soc. Exch. Club Brit. Isles for 1929, 9: 27, 1930.

Recorded localities: 1. Cieszyn, 2. Dzięgielów (herb. Žíla, leg. Žíla), 3. Lipowiec (WSRP, leg. Marciniuk), 4. Grodziec, 5. Bystra (herb. Žíla, leg. Žíla; WSRP, leg. Marciniuk), 6. Międzyrzecze Górne, 7. Hażlach, 8. Skoczów.

Former records: BB04, BD18, DA51, DE62, DF68 (Bielany), DF69 (Cracow, Botanic Garden), DG33, ED11, ED26, EE09, FC95, FD23, FD24, FD25, GE12 (Sęków) - Tacik 1980 (ut T. falciferum Markl.), Białasz and Głowacki 1999; Głowacki and Øllgaard 1999; Øllgaard et al. 2000, 2002b; Głowacki et al. 2004, 2005.

Taraxacum obtusifrons Marklund Acta Bot. Fenn. 26: $150,1940$.

Recorded localities: 1. Cieszyn, 2. Dzięgielów, 3. Lipowiec, 6. Międzyrzecze Górne, 7. Hażlach, 8. Skoczów.

Former record: DF69 (Cracow, Al. 3 Maja) - Tacik 1980.

In our study area, this distinct and easily identifiable species was observed at most localities, similarly abundant as in adjacent areas in the Czech Republic (Trávníček, unpubl.). It was found also in Slovakia (Kirschner and Štěpánek 1998), and in E Germany (Uhlemann 2003). Lack of records from most of Polish regions indicates that the occurence of the species may be restricted to some specific (southern) areas only.

Taraxacum ochrochlorum Haglund in Railonsala Ann. Soc. Vanamo 16 (5): 11, 1942.

Recorded localities: 1. Cieszyn (herb. Žíla, leg. Žíla), 2. Dzięgielów, 3. Lipowiec (herb. Žíla, leg. Žíla; WSRP, leg. 
Marciniuk), 4. Grodziec (herb. Žíla, leg. Žíla), 5. Bystra, 6. Międzyrzecze Górne (herb. Žíla, leg. Žíla).

Former records: DF69 (Cracow, between Rodno and Botanic Garden), DF78 (Podgórki Tynieckie), EC96, FB76, FC13 (Łomża), FC99, FD09, FD23, FE10 - Tacik 1980; Øllgaard et al. 2000, 2002a, b; Grużewska 2004.

In Poland, this species has been observed only in E part of the country. The abundant occurence of $T$. ochrochlorum in our study area is similar as in the adjacent region of the Czech Republic (Trávníček unpubl.). This species was found also in Slovakia (Kirschner and Štěpánek 1998), and in E Germany (Uhlemann 2003).

Taraxacum ohlsenii Haglund Meddelanden Horti Gotoburg. 11: 31, 1936.

Recorded localities: 1. Cieszyn, 2. Dzięgielów, 5. Bystra, 6. Międzyrzecze Górne, 7. Hażlach, 8. Skoczów.

Former records: BB04, BD37, BD38, BE13, CD49, ED21, FC13 (Łomża), FC55 - Głowacki and Øllgaard 1999; Ø11gaard et al. 2000, 2002a, b; Grużewska 2004; Głowacki et al. 2005.

In our study area, T. ohlsenii is a quite frequent species, observed at most localities. Earlier records from Poland are rather scarce but the hitherto ascertained distribution of this species indicates that it is present almost throughout the country. It is also known from the adjacent countries - in the Czech Republic (Kirschner and Štěpánek 1995, ut " $T$. praecociforme"), Slovakia (Kirschner and Štěpánek 1998, ut "T. praecociforme"), and Germany (Uhlemann 2003).

Taraxacum oxyrhinum Sahlin Svensk Bot. Tidskr. 69: 167, 1975.

Recorded localities: 2. Dzięgielów (herb. Žíla, leg. Žíla), 8. Skoczów (WSRP, leg. Marciniuk).

Former records: BB04, ED04, ED21, FD33, FB86, FC13 (Marianowo), FC55 - Øllgaard et al. 2000, 2002a; Grużewska 2004.

Most of the known localities are situated in NE Poland, and one locality is known from NW part of the country (Koszalin Coast region). Thus, the presence of $T$. oxyrhinum between towns of Cieszyn and Bielsko-Biała extends its distribution area to the southern regions. This species is known also in the Czech Republic (Kirschner and Štěpánek 1995), and E Germany (Uhlemann 2003).

Taraxacum pallidipes Marklund Acta Bot. Fenn. 23: 107, 1938.

Recorded localities: 2. Dzięgielów, 5. Bystra, 7. Hażlach.

Former records: CA38, CA39, DF68 (Cracow-Kryspinów), DF69 (Cracow-Wawel), DF69 (Cracow-Mydlniki), FD73, FC14 (Niewodowo), FC55 - Tacik 1980; Øllgaard et al. 2000, 2002b, Grużewska 2004.
This species has been observed at two localities in NW Poland (Kaszuby Coast), and at three localities in NE part of the country (Wysoka Mazowiecka Upland, Żelechów Upland, lower Narew River valley); older observations were made in Cracow area. This species is also known in the Czech Republic (Kirschner and Štěpánek 1995), Slovakia (Kirschner and Štěpánek 1998), and E Germany (Uhlemann 2003).

Taraxacum pectinatiforme H. Lindberg Acta Soc. Fauna Fl. Fenn. 29 (9): 13, 30, 1908.

Recorded localities: 5. Bystra, 7. Hażlach.

Former records: BB04, CA39, DE93, DF45, DF57 (Krzeszowice), DF69 (Bronowice Małe, Mydlniki, Cracow-Bonarka), EF70 (Rżąka), EG20 (Lasek), FB76, FC64, FC99, FD16, FD23, FD33, FD72 - Tacik 1980; Øllgaard et al. 2000, 2002a, b.

Taraxacum piceatum Dahlstedt Arkiv Bot., Stockholm, 9 (10): 11, 1910.

Recorded localities: 2. Dzięgielów, 3. Lipowiec (OL, leg. Trávníček; WSRP, leg. Marciniuk), 4. Grodziec (WSRP, leg. Marciniuk), 5. Bystra, 6. Międzyrzecze Górne, 7. Hażlach (herb. Žíla, leg. Žíla), 8. Skoczów (herb. Žíla, leg. Žíla).

Former records: BB04, BE13, CA39, DA51, DE93, DF36, DF69 (Bronowice Małe), DF79 (Sidzina), ED29, FB76, FC14 (Niewodowo), FD56 (Dulowa) - Tacik 1980; Øllgaard et al. 2000, 2002a, b; Grużewska 2004.

Taraxacum pronilobum H. Øllgaard Bot. Notiser 131: 513, 1978 (Fig. 11)

Main diagnostic features of the species: usually rather slender plant; leaves erect, slightly hairy to almost glabrous; lateral lobes 3-5, recurved, most often with conspicuously convex distal margin, not infrequently alternate; interlobes narrow, unblotched, only inconspicuously dentate; terminal lobe often asymmetrical; petioles long, narrow, pallid, usually only slightly pink coloured; outer bracts \pm patent, rather sigmoid, dark green, almost unbordered.

Recorded localities: 1. Cieszyn (OL, leg. Trávníček; herb. Žíla, leg. Žíla), 6. Międzyrzecze Górne (OL, leg. Trávníček; herb. Žíla, leg. Žíla; WSRP, leg. Marciniuk), 8. Skoczów (OL, leg. Trávníček).

T. pronilobum is a new species for Polish flora. The localities found in our study area reflect the scattered occurence of this species in the adjacent regions of the Czech Republic (Trávníček unpubl.). It is also reported from Denmark where it was described.

Taraxacum pulchrifolium Marklund Acta Bot. Fenn. 23: 110,1938 .

Recorded localities: 1. Cieszyn (WSRP, leg. Marciniuk), 2. Dzięgielów, 3. Lipowiec (WSRP, leg. Marciniuk), 4. Grodziec (WSRP, leg. Marciniuk), 5. Bystra (WSRP, leg. Marciniuk), 6. Międzyrzecze Górne, 7. Hażlach, 8. Skoczów. 


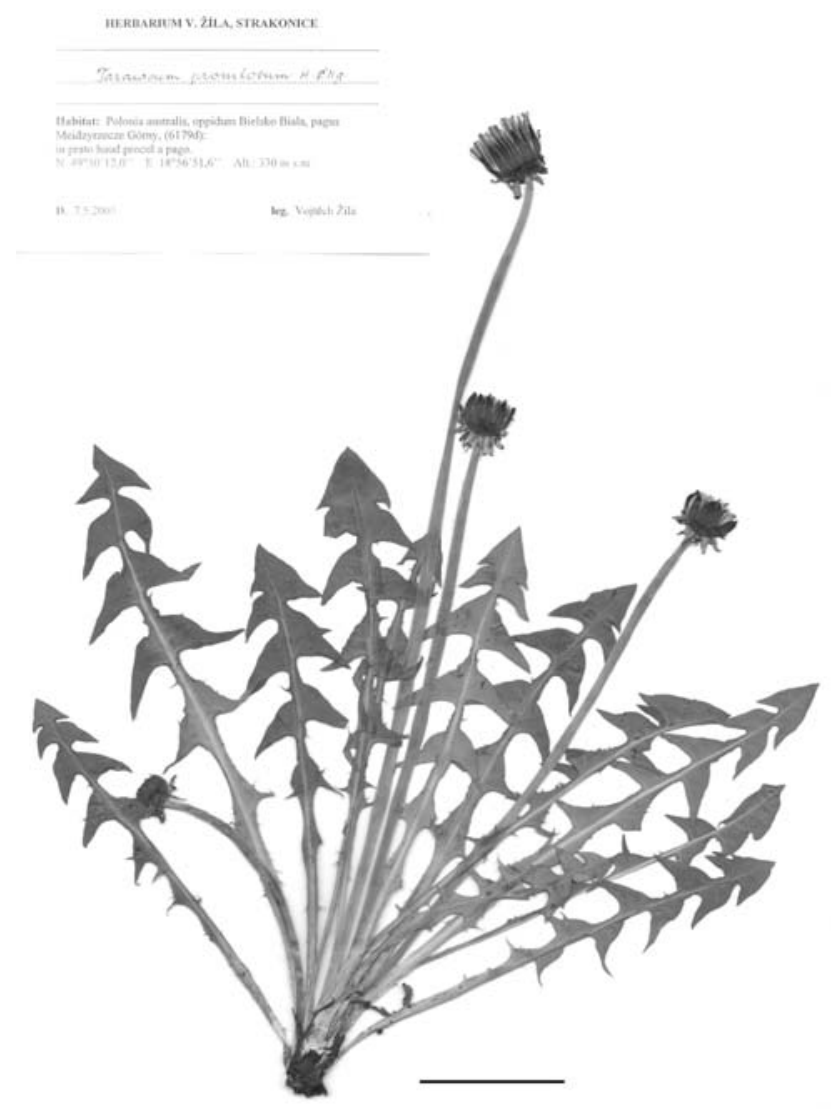

Fig. 11. Taraxacum pronilobum, habitus, herbarium specimen, deposited in herbarium Žíla (locality no. 6); scale bar $=5 \mathrm{~cm}$.

Former records: DE93, DF58 (Zabierzów), DF69 (CracowŁobzów), ED05, ED49, EE09, EF60 (Prokocim), FC13 (Łomża, Kalinowo), FC64, FC74, FC81, FC99, FD07, FD12, FD16, FD23, FD25, FD33, FE10, GE02 (Nowiny) Tacik 1980; Białasz and Głowacki 1999; Głowacki and Øllgaard 1999; Øllgaard et al. 2000, 2002b; Grużewska 2004.

All earlier found localities of T. pulchrifolium in Poland are situated in the eastern half of the country. However, this species is known in Slovakia (Kirschner and Štěpánek 1998), in entire territory of the Czech Republic (Kirschner and Štěpánek 1998), and also in E Germany (Uhlemann 2003). Thus, it is likely to be found an occurence of T. pulchrifolium also in western part of Poland. In our study area the species was frequent and observed at all the localities.

Taraxacum rhamphodes Haglund Bot. Notiser 1935: 120, 1935 (Fig. 12)

Main diagnostic features of the species: usually robust plant; leaves mid-green, rather broad, most often with \pm undivided regular lobes; lateral lobes 4-5(-6), usually patent, sometimes alternate, with distal margin \pm convex, lowermost lobes often with apex bent upwards; interlobes usually without remarkable teeth; terminal lobe variable, often forming rounded basal lobules; petioles more or less winged, light pink-violet; outer bracts mostly recurved, grey-green, pruinose on upper surface, with a pink tip, bordered.

Recorded localities: 1. Cieszyn (OL, leg. Trávníček), 8. Skoczów (OL, leg. Trávníček).

T. rhamphodes is a new species in Polish flora. In our study area, it was very rarely found at two localities only. It is also rare in the Czech Republic, where it is restricted to the NE part of the country, i.e. the region adjacent to our area. It was also observed in E Germany (Uhlemann 2003). Distribution of T. rhamphodes in Poland is probably restricted to some specific areas only.

Taraxacum sellandii Dahlstedt Bergens Mus. Aarbok 1923-1924 (6): 19, 1925.

Recorded locality: 8. Skoczów (herb. Žíla, leg. Žíla).

Former records: AB42, AB63, BD49, CA37, CA39, CB09, CD40, CD41, CD60, DA51, DF68 (Kryspinów), EF33 (Swoszowice), EF60 (Łęg), FE01 - Tacik 1980; Øllgaard

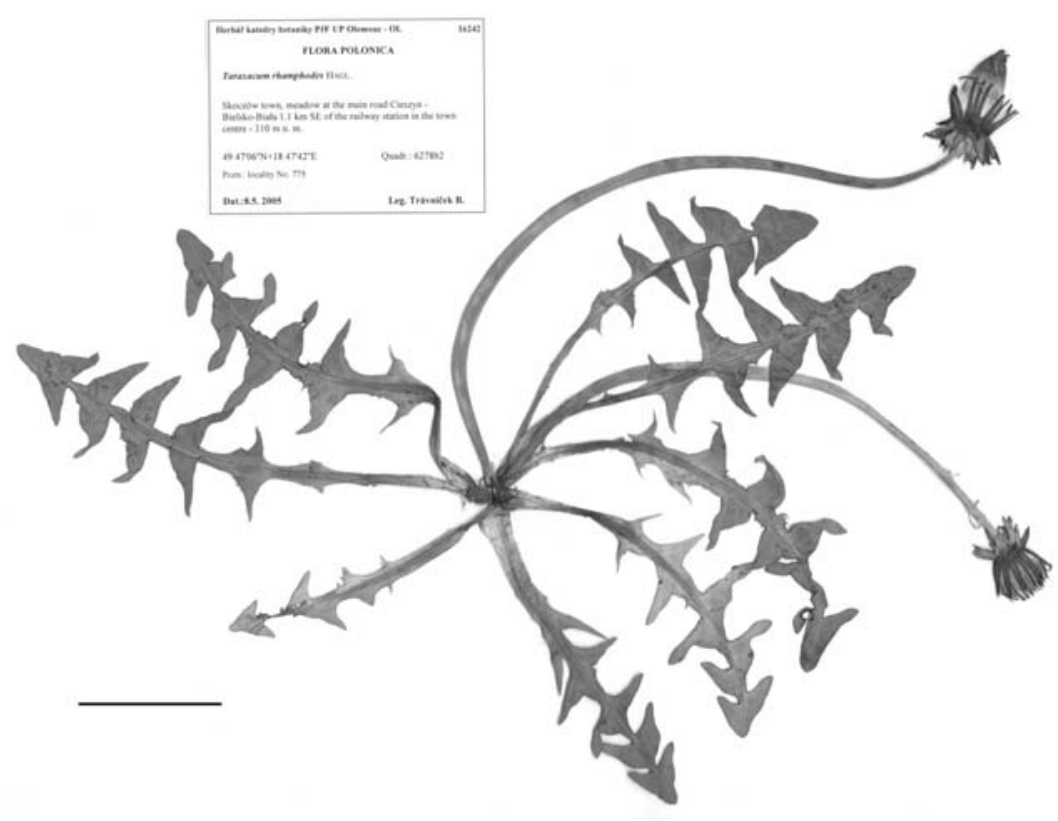

Fig. 12. Taraxacum rhamphodes, habitus, herbarium specimen, deposited in herbarium OL (locality no. 8); scale bar $=5 \mathrm{~cm}$. 
et al. 2000, 2002b; Głowacki and Czarna 2003; Głowacki et al. 2005.

Taraxacum sertatum Kirschner, H. Øllgaard et Štěpánek Preslia 69: 49, 1997.

Recorded localities: 2. Dzięgielów (WSRP, leg. Marciniuk), 5. Bystra, 6. Międzyrzecze Górne, 7. Hażlach, 8. Skoczów.

Former records: BE13, DF12, DF43, EE76 - Øllgaard et al. 2002c.

All the earlier found localities in Poland are located in the southern part of the country. Thus, it is likely to occur frequently in entire southern Poland, similarly as in entire territory of the Czech Republic (Kirschner and Štěpánek 1997). It is known also from E Germany (Uhlemann 2003).

Taraxacum sinuatum Dahlstedt Bergens Mus. Aarbok 1923-1924 (6): 23, 1925.

Recorded localities: 3. Lipowiec (herb. Žíla, leg. Žíla; WSRP, leg. Marciniuk), 7. Hażlach (herb. Žíla, leg. Žíla), 8. Skoczów (herb. Žíla, leg. Žíla).

Former records: AB53, AB63, BD18, BD36, CA37, DE93, DF12, DF58 (Zabierzów), DF69 (Cracow, Botanic Garden, Mydlniki), ED29, ED49, EE09, EF33 (Swoszowice), FC13 (Stara Łomża, Łomża, Kalinowo), FC14 (Drozdowo), FC64, FC95, FC99, FD07, FD09, FD16 ("verissime"), FD33, FE10 - Tacik 1980; Głowacki and Øllgaard 1999; Øllgaard et al. 2000, 2002b; Grużewska 2004; Głowacki et al. 2005.

Taraxacum sublaeticolor Dahlstedt Arkiv Bot., Stockholm, 19 (18): 17, 1925.

Recorded locality: 1. Cieszyn (herb. Žíla, leg. Žíla).

Former records: AB42, CA37, CD40, DA51, DF67 (Baczyn), EC95, EC96, ED06, EF72, FB86, FC13, FC14 (Niewodowo), FD16, FD23, FD25, FD27, FD33, GD23 - Tacik 1980; Głowacki and Øllgaard 1999, Øllgaard et al. 2000; Øllgaard et al. 2002a, b; Głowacki and Czarna 2003; Grużewska 2004; Głowacki et al. 2005.

Taraxacum subxanthostigma M. P. Christiansen ex H. Øllgaard Bot. Notiser 131: 516, 1978.

Recorded locality: 8. Skoczów (OL, leg. Trávníček).

Former records: CA38, FC54 - Øllgaard et al. 2000, 2002b.

In Poland, this species has been found only in two localities: one is located in NW part (Gdańsk and Kaszuby Coast) and another in NE part (North Podlasie Lowland Bielsk Plain) of the country. Our ascertained locality is therefore first observation of this species in southern Poland. T. subxanthostigma occurs also in the adjacent region of the Czech Republic (Trávníček unpubl.), and also in E Germany (Uhlemann 2003).
Taraxacum undul atifloru m M. P. Christiansen Dansk Bot. Arkiv 9 (2): 28, 1936.

Recorded localities: 1. Cieszyn (herb. Žíla, leg. Žíla), 2. Dzięgielów, 3. Lipowiec (herb. Žíla, leg. Žíla), 4. Grodziec, 5. Bystra (herb. Žíla, leg. Žíla), 6. Międzyrzecze Górne, 7. Hażlach, 8. Skoczów (herb. Žíla, leg. Žíla).

Former records: DF69 (Cracow, Al. 3 Maja), DF69 (Łobzów), EC94, EC95, ED11, ED29, FD65 - Tacik 1980 (ut "T. hastatum Markl., syn.: T. undulatiflorum"), Głowacki and Øllgaard 1999 (ut "T. undulatiflorum, syn.: T. hastatum.”), Øllgaard et al. 2000, 2002b.

Information about the occurence of $T$. undulatiflorum in Poland must be revised: it was found that this name was used for two species in the past: besides the T. undulatiflorum itself, described from Denmark, also for the species identified sometimes as T. hastatum Markl. 1926 (taxon described in Finland). For the latter taxon, however, the correct name is T. homoschistum H. Øllgaard 2006 since there is another, older homonym $T$. hastatum Brenner 1925, for another species (see Øllgaard 2006).

Taraxacum undulatiforme Dahlstedt Arkiv Bot., Stockholm, 19 (18): 18, 1925.

Recorded localities: 4. Grodziec (OL, leg. Trávníček; herb. Žíla, leg. Žíla; WSRP, leg. Marciniuk), 8. Skoczów (T. cf. undulatiforme, OL, leg. Trávníček; herb. Žíla, leg. Žíla).

Former record: BE18 - Øllgaard et al. 2002b.

In Poland, only one record has been known of the presence of T. undulatiforme - in SW part of the country (Milicz and Głogów Plain - Żmigród Basin). The species is known also in the Czech Republic (Kirschner and Štěpánek 1995), where it has scattered occurence, especially in region adjacent to our study area, and was found also in E Germany (Uhlemann 2003).

Taraxacum undulatum H. Lindberg et Marklund in Marklund Acta Soc. Fauna Fl. Fenn. 34 (7): 5, 1911.

Recorded localities: 1. Cieszyn (herb. Žíla, leg. Žíla), 3. Lipowiec (herb. Žíla, leg. Žíla; WSRP, leg. Marciniuk), 7. Hażlach (herb. Žíla, leg. Žíla; WSRP, leg. Marciniuk).

Former records: BE13, DF58 (Bolechowice, Zabierzów), DF78 (Podgórki Tynieckie), DF78 (Skawina - “ $\pm ” T$. undulatum), DF79 (Sidzina), FC64, FC99, FD07, FD09, EE09 - Tacik 1980; Øllgaard et al. 2000, 2002b.

Taraxacum urbicola Kirschner, Štěpánek et Trávníček ined.

Recorded localities: 2. Dzięgielów (OL, leg. Trávníček), 3. Lipowiec (OL, leg. Trávníček), 6. Międzyrzecze Górne (OL, leg. Trávníček), 7. Hażlach (OL, leg. Trávníček), 8. Skoczów (OL, leg. Trávníček).

Former records: BE13, EF25 - Øllgaard et al. 2002c.

T. urbicola is a quite recently detected species, for its formal description see Trávníček et al. (2007). In our study 


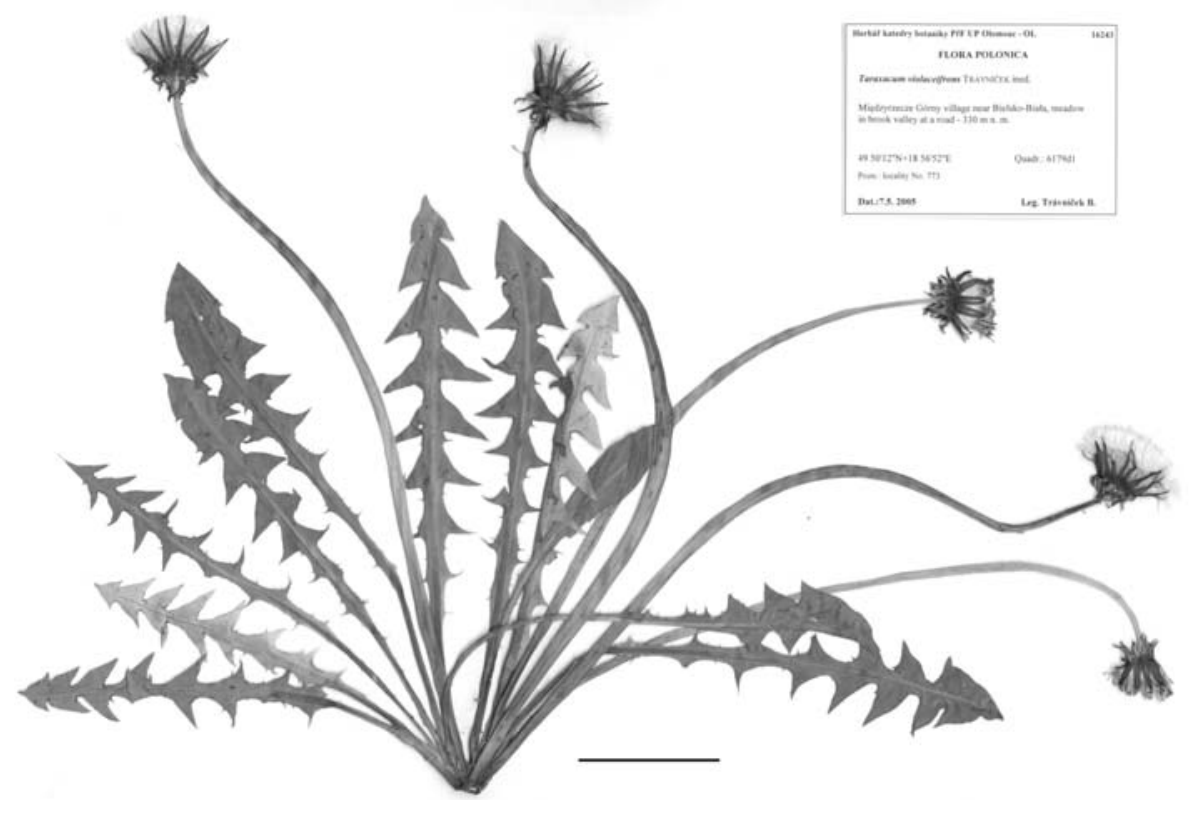

Fig. 13. Taraxacum violaceifrons, habitus, herbarium specimen, deposited in herbarium OL (locality no. 6); scale bar $=5 \mathrm{~cm}$. area it was dispersed, similarly as in the adjacent region of the Czech Republic (Trávníček and Štěpánek 2007). T. urbicola is known also from SE Germany and W Slovakia (Trávníček and Štěpánek 1. c.). In Poland, the species was formerly found at two localities: one in SW part (Silesian and Lusatian Lowland - Lubin Upland), and the other in SE part of the country (Nida Basin - Garb Pińczowski).

Taraxacum valens Marklund Acta Bot. Fenn. 23: 119, 1938.

Recorded locality: 5. Bystra (WSRP, leg. Marciniuk).

Former records: AB53, DA51, DE32, DF69 (Cracow-Łagiewniki), DF89 (Brzezina Krzywaczańska), EC95, EC96, ED04, ED11, ED14, EE76, FB86, FC64, FC74, FD07, FD25, FD33, FE00 - Tacik 1980; Głowacki and Øllgaard 1999; Øllgaard et al. 2000, 2002a, b.

Taraxacum violaceifrons Trávníček ined. (Fig. 13)

Main diagnostic features of the species: a medium-sized, rather slender plant; leaves greyish green, regularly divided, lobes and interlobes with inconspicuous teeth only; lateral lobes 4-6, \pm triangular, usually short, very acute, patent to slightly recurved; interlobes \pm flat, rather broad, with narrow tar coloured border; terminal lobe acute, sometimes mucronate; petioles narrow, markedly pink-violet; outer bracts recurved to reflexed, often suffused light lilac; achenes with markedly tuberculous, never smooth, lower half of the achene body.

Recorded localities: 2. Dzięgielów (OL, leg. Trávníček), 6. Międzyrzecze Górne (OL, leg. Trávníček; herb. Žíla, leg. Žíla).

T. violaceifrons is a new species in Poland. It is a quite recently detected taxon, for its formal description see Trávníček et al. 2007. In our study area, the species was observed at only two localities. In the adjacent region of the Czech Republic, T. violaceifrons is also rare, while in the remaining areas of the eastern part of the country it is abundant (see Trávníček and Štěpánek 2007). Such a distribution is conditioned with relatively humid (oceanic) climate in the region of the town of Cieszyn/Český Těšín (T. violaceifrons prefers dry biotopes).

\section{ACKNOWLEDGEMENTS}

We thank Mr Hans Øllgaard (Viborg, Denmark) for verification of determination of Taraxacum bellum and T. hamatum, and anonymous reviewer for comments related to the paper.

\section{LITERATURE CITED}

BIAŁASZ I.U., GŁOWACKI Z. 1999. Przyczynek do flory mniszków Poleskiego Parku Narodowego (A contribution to the Taraxacum flora of the Poleski National Park). Fragm. Flor. Geobot. Polonica 6: 5-13. (in Polish with English summary)

GŁOWACKI Z., CZARNA A. 2003. Gatunki rodzaju Taraxacum (Asteraceae) z terenu Wielkopolski (Taraxacum species (Asteraceae) in Wielkopolska (Mid-Western Poland)). Acta Sci. Pol. Biologia 2 (1-2): 51-54. (in Polish with English summary)

GŁOWACKI Z., KRECHOWSKI J., ØLLGAARD H. 1998. Taraxacum excurssions, Baltic Sea coast area N of Gdynia, Poland 8-9 May 1997. Taraxacum species list with comments. Taraxacum Newsletter 20: 14-17.

GŁOWACKI Z., ØLLGAARD H. 1999. Taxa of Taraxacum (Asteraceae) in the Mazowsze and Podlasie regions (Poland). Fragm. Flor. Geobot. 44 (1): 49-57.

GŁOWACKI Z., ØLLGAARD H., CZARNA A. 2005. Gatunki rodzaju Taraxacum (Asteraceae) w Polsce. Cz. 3. Wielkopolska (Species of genus Taraxacum (Asteraceae) in Poland. Part 3. Wielkopolska region. Fragm. Flor. Geobot. 12 (2): 275-280. (in Polish with English summary)

GŁOWACKI Z., ØLLGAARD H., KRECHOWSKI J. 2004. Genus Taraxacum in the herbarium of University of Silesia. Bad. Fizjogr. Pol. Zach. B 53: 107-112.

GRUŻEWSKA T. 2004. Rodzaj Taraxacum (Asteraceae) na Ziemi Łomżyńskiej (The genus Taraxacum (Asteraceae) in the Łomża region). Fragm. Flor. Geobot. Polonica, Suppl. 6: 65-75. (in Polish with English summary) 
KIRSCHNER J., ŠTĚPÁNEK J. 1995. Současný stav taxonomického výzkumu rodu Taraxacum v České a Slovenské republice. Zpr. Čes. Bot. Společ. 29 (1994): 1-9. (in Czech with English summary)

KIRSCHNER J., ŠTĚPÁNEK J. 1997. Notes on the series of Taraxaca Exsiccata, Fasc. V-VII. (Studies in Taraxacum 16.). Preslia 69: 35-58.

KIRSCHNER J., ŠTĚPÁNEK J. 1998. Taraxacum Weber (Cichoriaceae), půpava. In: Marhold K., Hindák F. (eds). Checklist of non-vascular and vascular plants of Slovakia, Veda, Bratislava, pp. 640-643. (in Slovak with English summary)

KONDRACKI J. 2002. Geografia regionalna Polski. Wyd. Nauk. PWN, Warszawa. (in Polish)

ØLLGAARD H. 1978. New species of Taraxacum from Denmark. Bot. Notiser 131: 497-521.

ØLLGAARD H. 2003. New species of Taraxacum, sect. Ruderalia, found in Central and Northern Europe. Preslia 75: 137-164.

ØLLGAARD H. 2006. Further new Taraxacum species (Asteraceae, Cichorieae) from northern Europe. Willdenowia 36: 693-706.

ØLLGAARD H., GŁOWACKI Z., KRECHOWSKI J. 2000. Gatunki rodzaju Taraxacum (Asteraceae) w Polsce. Cz. 1. Pomorze, Mazowsze i Podlasie (Species of genus Taraxacum (Asteraceae) in Poland. Part 1. Pomorze, Mazowsze i Podlasie regions). Fragm. Flor. Geobot. Polonica 7: 5-62. (in Polish with English summary)

ØLLGAARD H., GŁOWACKI Z., GRUŻEWSKA T. 2002a. Gatunki rodzaju Taraxacum Wigg. w Kotlinie Biebrzańskiej i Dolinie Dolnej Narwi (Species of genus Taraxacum Wigg. in Kotlina Biebrzańska and Narew river valley). Drozdowskie Zesz. Przyr. 2: 9-58. (in Polish)

ØLLGAARD H., GŁOWACKI Z., FALKOWSKI M., KRECHOWSKI J. 2002b. Gatunki rodzaju Taraxacum (Asteraceae) w Polsce. Cz. 2 (Species of genus Taraxacum (Asteraceae) in Poland. Part 2). Fragm. Flor. Geobot. Polonica 9: 3-20. (in Polish with English summary)

ØLlGAARD H., GŁOWACKI Z., FALKOWSKI M., KRECHOWSKI J. 2002c. Nowe dla polskiej flory gatunki z rodza- ju Taraxacum (Asteraceae) (Species of genus Taraxacum (Asteraceae) new to the Polish flora). Fragm. Flor. Geobot. Polonica 9: 21-35. (in Polish with English summary)

MIREK Z., PIĘKOŚ-MIRKOWA H., ZAJĄC A., ZAJĄC M. 2002. Flowering plants and pteridiophytes of Poland. A checklist. Biodiversity of Poland (ed. Z. Mirek) 1, pp. 1-442, W. Szafer Institute of Botany, Polish Academy of Sciences, Kraków.

SACKWITZ P., HORN K., LOOS G.H., ØLLGAARD H., JUNG K. 1998. Taraxacum F.W.Wigg. (Asteraceae = Compositae). In: Wisskirchen R., Haeupler H., Standardliste der Farn- und Blütenpflanzen Deutschlands mit Chromosomenatlas von $\mathrm{F}$. Albert, p. 496-515, Ulmer, Stuttgart.

TACIK T. 1980. Taraxacum Wiggers, Mniszek (Dmuchawiec) (Taraxacum Wiggers, Dandelion). In: Jasiewicz A. (ed.), Flora polska. Rośliny naczyniowe Polski i ziem ościennych (Polish Flora. Vascular plants of Poland and adjacent territories). 14, pp. 7-199. Państwowe Wydawnictwo Naukowe, Warszawa-Kraków. (in Polish)

TRÁVNÍČEK B., ŠTĚPÁNEK J. 2007. Nové nebo méně známé druhy Taraxacum sect. Ruderalia nalezené ve stædní Evropě (New or less known species of Taraxacum sect. Ruderalia found in Central Europe). Zpr. Čes. Bot. Společ. 42 (in prep.). (in Czech with English summary)

TRÁVNÍČEK B., ŠTĚPÁNEK J., KIRSCHNER J. 2007. Five new Taraxacum species, sect. Ruderalia, from the Central Europe and Denmark (in prep.).

TRÁVNÍČEK B., ŠTĚPÁNEK J., LUSTYK P. 2000. Zpráva o pracovním semináø "Rod Taraxacum na støední Moravě" (Olomouc 1996) (Taraxacum Workshop in Central Moravia, Olomouc, 1996). Zpr. Čes. Bot. Společ. 34 (1999): 257-260. (in Czech with English summary)

UHLEMANN I. 2003. Die Gattung Taraxacum (Asteraceae) im östlichen Deutschland. Mitt. Florist. Kart. Sachsen-Anhalt, Sonderheft 2003: 1-136.

ZAJAC A. 1978. Atlas of distribution of vascular plants in Poland. Taxon 27: 481-484. 